\title{
Mineralogy, geochemistry and parent rock of Décio bauxite-bearing lateritic profile (Rondon do Pará, Eastern Amazon)
}

\author{
Pabllo Henrique Costa dos Santos ${ }^{1 *}$ (D), Marcondes Lima da Costa' (D)
}

\begin{abstract}
Cenozoic world-class bauxite deposits developed on sedimentary sequences of the Parnaíba and Amazon Basins. The Décio pilot mine, excavated in the Rondon do Pará bauxite deposit, exposes a $3 \mathrm{~m}$ thick bauxite-bearing lateritic profile on the top of a $350 \mathrm{~m}$ high plateau. From the base to the top, this profile is composed of clayey bauxite; porous microcrystalline bauxite; spherulitic ferro-aluminous duricrust, fragmentary on the top; as well as loose ferro-aluminous spherulites and nodules, embedded in clay. The lower horizons represent a classic lateritic succession, while the top of the profile was produced through post-lateritic reworking. During this process, $\mathrm{Ga}, \mathrm{Cr}, \mathrm{Mo}, \mathrm{As}, \mathrm{Pb}, \mathrm{Hg}$, $\mathrm{Sb}, \mathrm{Zn}, \mathrm{V}$ and $\mathrm{Sc}$ were captured by the iron oxi-hydroxides; and $\mathrm{REE}, \mathrm{Hf}, \mathrm{Nb}, \mathrm{Ta}, \mathrm{Y}$ remained carried by relict zircon. Isocon diagram and mass balance demonstrate the affinity of the bauxite with claystone from Itapecuru Formation.
\end{abstract}

KEYWORDS: weathering; gibbsite; aluminum.

\section{INTRODUCTION}

Lateritization events affected the Amazon region during the Cenozoic, resulting in the formation of extensive bauxite-bearing lateritic covers (Costa 1991, Théveniaut and Freissynet 2002, Vasconcelos et al.2015), including the large deposits of Trombetas, Paragominas, Juruti and Rondon do Pará, which make up one of the largest bauxite provinces in the world (Boulangé and Carvalho 1997, Lucas 1997, Kotschoubey et al.2005, Costa et al.2014, Oliveira et al. 2016, Lima 2018). Three of them are currently being exploited (Trombetas, Paragominas and Juruti) and supply the alumina refinery in Barcarena, Pará. Some smaller deposits are located in Pitinga, Amazonas; and Carajás, Pará (Horbe and Costa 1999, Horbe and Anand 2011, Negrão and Costa 2021, Fig. 1A).

Over the past four decades, mineral exploration has motivated studies about the origin of bauxites in the Amazon, interpreting the Trombetas and Juruti deposits as products of regional lateritization (Boulangé and Carvalho 1997, Lucas 1997). In addition to the weathering, polyphasic events such as erosion, transportation and deposition of lateritic materials also played an essential role in the structuration of the lateritic profiles, as demonstrated in the Paragominas and Açailândia deposits (Truckenbrodt and Kotschoubey

\footnotetext{
${ }^{1}$ Universidade Federal do Pará - Belém (PA), Brazil.E-mails: phsantos@ufpa.br, marcondeslc@gmail.com

${ }^{*}$ Corresponding author.
}

1981, Kotschoubey et al. 1987). The post-lateritic events also include the formation of the covering material, e.g., the Belterra Clay unit, which comprises a friable yellow to red clay layer, with significant mineralogical and chemical affinity with the underlying bauxite-bearing laterites (Truckenbrodt and Kotschoubey 1981, Kotschoubey et al. 2005, Cruz 2011, Negrão et al. 2018).

The overall structures of of the Amazon's bauxite deposits are very similar. The bottom of the profiles usually comprises a horizon of massive microporous light pink to reddish bauxite (Costa et al. 2014). This horizon is covered by cryptocrystalline nodular bauxite, occasionally succeeded by nodular to brecciated lateritic duricrust, rich in iron oxi-hydroxides (goethite and hematite); and overlayed by ferruginous spherulites and gibbsite nodules embedded in clay (Costa 2016).

From 1974 to 1980, the Companhia Brasileira de Alumínio conducted the first exploration program in Rondon do Pará (Pará, Eastern Amazon). In 2005, Votorantim Metais (now NEXA Resources) restarted mineral prospecting in this area and identified large deposits with available $\mathrm{Al}_{2} \mathrm{O}_{3}$ contents ranging from 39.9 to $52.4 \% ; 14.8$ to $35.1 \%$ of $\mathrm{Fe}_{2} \mathrm{O}_{3}$; and 3.1 to $4.3 \%$ of reactive $\mathrm{SiO}_{2}$ (Oliveira et al. 2016). In addition, three pilot open-pit mines named Ciriaco, Branco and Décio were excavated in order to enable metallurgical testing, providing new outcrops of bauxite-bearing lateritic profiles.

Despite the latest advances, more accurate comprehension of the origin and evolution of bauxites in the Amazon still comes up against the lack of data as most deposits are often covered by rainforest, sediments and oxysols (latossolo in the brazilian soil classification, Santos et al. 2018). Moreover, the laterites are currently subjected to chemical 


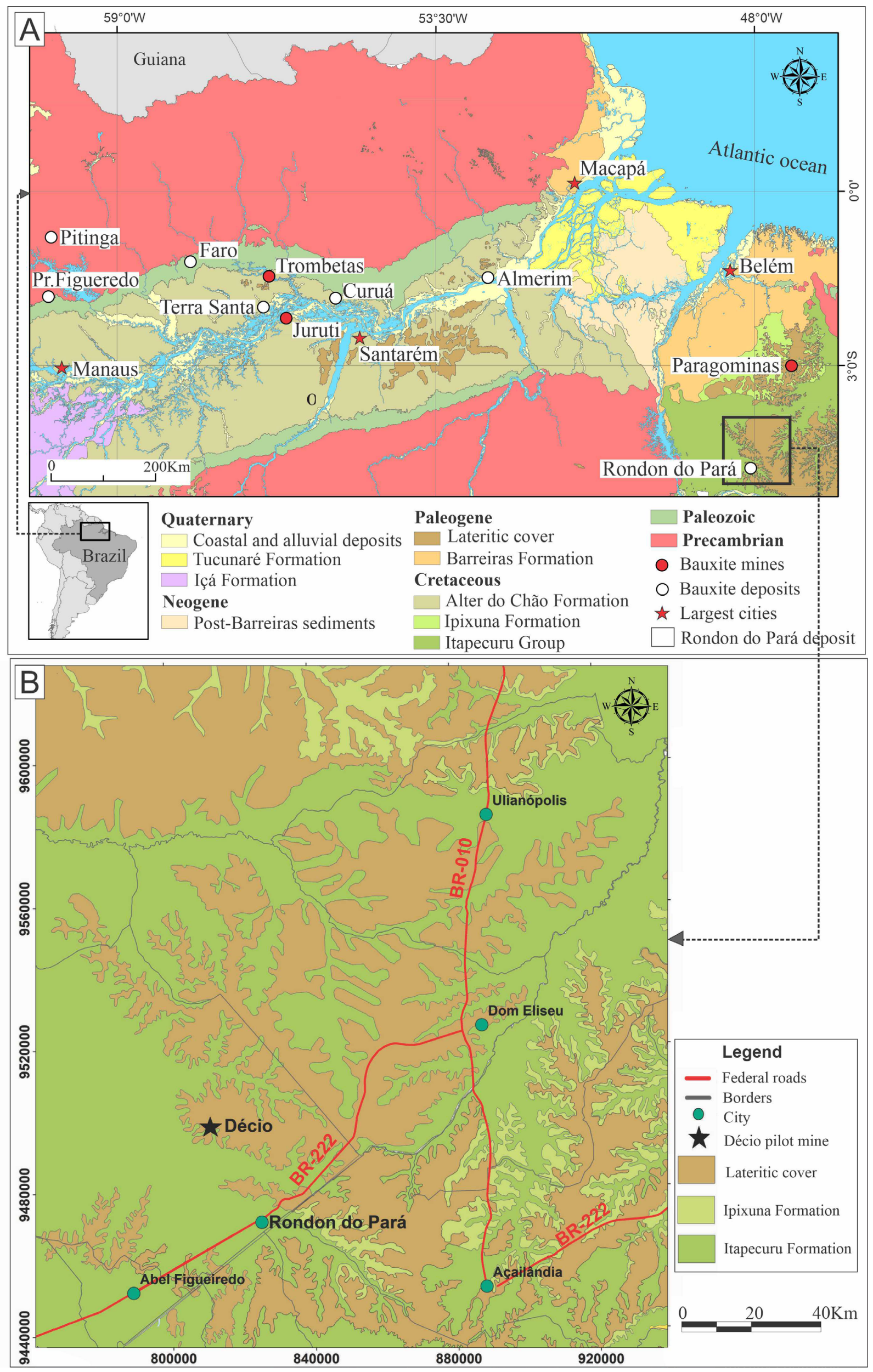

Figure 1. (A) Geological map of Eastern Amazon (modified from Bizzi et al. 2003) with the location of the primary bauxite deposits. (B) The geology of Rondon do Pará region (modified from Bizzi et al. 2003), highlighting the location of the Décio pilot mine. 
weathering, resulting in obliteration of features and absence of relics of the parent material (Boulangé and Carvalho 1997, Horbe and Costa 1999, 2005). Therefore, this study aims to improve the understanding of the mineralogical, textural and chemical zonation of the recently exposed Décio bauxite-bearing lateritic profile, adding new information to the weathering history of the Amazon region.

\section{GEOLOGICAL SETTING}

The geology of the Rondon do Pará region comprises the sedimentary sequences of the Itapecuru Formation (Grajaú Basin) and its lateritic covers (Bizzi et al. 2003, Fig. 1B). The Itapecuru Formation consists of sandstone layers and shale lenses, with swaley and hummocky cross-stratification, mud couplets and mass slide, originated in a transgressive delta, with tides and storms, during the Mesoalbian-Neocretace (Rossetti 2001, Vaz et al. 2007).

During the Paleogene, the southern region of the Grajaú Basin remained sedimentation free. In this scenario, extensive lateritic blankets were developed on the sedimentary sequences of the Itapecuru Formation (Grubb 1979, Góes 1995). From the bottom to the top, these lateritic profiles are composed of clayey bauxite, massive bauxite, ferro-aluminous duricrust, fragmentary ferro-aluminous duricrust, spherulitic horizon and nodular bauxite horizon. Finally, a 12 to $15 \mathrm{~m}$ layer of the Belterra Clay unit covers the laterites (Pantoja 2015, Negrão et al. 2018).

The affinity of the Belterra Clay with the underlying bauxite-bearing lateritic profiles suggests that it was originated from their chemical decomposition (Truckenbrodt and Kotschoubey 1981, Horbe and Costa 1999, 2005). However, deposition of clayey sediments and subsequent weathering were also proposed (Truckenbrodt et al. 1995). The Rondon do Pará region landscape comprises dissected plateaus, with an altitude of 150 to $350 \mathrm{~m}$, increasing from north to south. These plateaus are surrounded by broad valleys, with local unevenness of 50 to $100 \mathrm{~m}$ (Dantas and Teixeira 2013).

\section{MATERIALS AND METHODS}

Five profiles were sampled on the lowest bench of the Décio pilot mine (10 $\mathrm{m}$ away from each other), aiming to verify possible lateral variations in texture, but as they were not substantial, only vertical description will be presented. Thirty-five $2 \mathrm{~kg}$ samples were collected, as follows: profile 1 (eight samples); profile 2 (seven samples); profile 3 (six samples); profile 4 (eight samples); profile 5 (six samples). The other benches expose the Belterra Clay, which was not deeply investigated (Fig. 2A).

The micromorphological aspects were analyzed in twenty petrographic thin sections of selected samples from the five profiles in the LEICA DM 2700 P microscope (coupled with LEICA MC $170 \mathrm{HD}$ camera) and adopting the terminologies defined by Delvigne (1999). Two grams of raw samples were crushed in agate mortar to produce powders (less than $25 \mu \mathrm{m}$ ) that were analyzed by X-Ray Diffraction
(XRD) using a Bruker D2 PHASER equipment, with $\mathrm{Cu}$ $\mathrm{K} \alpha \mathrm{X}$-ray source, operating at $30 \mathrm{kV}$ and $10 \mathrm{~mA}$. The analysis range was $5-75^{\circ} 2 \theta$, with a step size of 0.02 and a counting time of $0.2 \mathrm{~s}$ per step.

For the identification of heavy minerals, six samples from profile 4 were selected. Two hundred grams of each sample were comminuted in a jaw crusher and shatterbox mill. Subsequently, the $250-125 \mu \mathrm{m}$ and $125-63 \mu \mathrm{m}$ fractions were separated via wet sieving and heavy minerals were concentrated by immersion in bromoform. Then, Frantz magnetic separation was performed to remove opaque minerals. Eventually, final concentrates (transparent heavy minerals) were identified and quantified in thin sections under the optical microscope.

The whole-rock chemical composition of twelve raw samples from profiles 4 and 5 was determined at the ACME Analytical Laboratories Ltda., Canada. Samples were fused with lithium tetraborate and the glass formed was then digested employing diluted nitric acid. Precious and base metals were extracted using aqua regia. Major elements were analyzed by Optical Emission Spectrometry with Inductively Coupled Plasma (ICP-OES) and trace elements were determined by Mass Spectrometry with Inductively Coupled Plasma (ICP-MS). Loss on ignition (LOI) was calculated after calcination at $1,000^{\circ} \mathrm{C}$. All the elements analyzed are presented, except $\mathrm{CaO}, \mathrm{Na}_{2} \mathrm{O}, \mathrm{Cd}, \mathrm{Tl}$ and $\mathrm{Ni}$, as their concentrations are invariably below ICP-OES and ICP-MS detection limits.

The percentages of hematite, goethite, kaolinite, gibbsite and anatase in each sample were determined by stoichiometric calculation, using the chemical composition of raw samples. Therefore, the entire content of $\mathrm{SiO}_{2}$ was attributed to kaolinite since quartz occurs in minimal quantities, not detectable via XRD. The aluminum contents not consumed by kaolinite were assigned to the gibbsite. As rutile occurs in trace amounts, the entire content of $\mathrm{TiO}_{2}$ was attributed to anatase. Finally, contents of $\mathrm{Fe}_{2} \mathrm{O}_{3}$ were assigned to hematite plus goethite.

Mass balance calculations approached mobility of elements during weathering according to the Eq. 1 :

$X$ Change $(\%)=\left[\left\{\left(\frac{X \text { weathered }}{I \text { weathered }}\right) /\left(\frac{X \text { parent }}{I \text { parent }}\right)\right\}-1\right] \times 100$

In which:

$\mathrm{X}$ Change (\%):the enrichment or depletion factor of element $\mathrm{X}$ during weathering;

$\mathrm{X}_{\text {weathered }}$ : the content of element $\mathrm{X}$ in the lateritic profile;

$\mathrm{X}_{\text {parent }}$ : the content of element $\mathrm{X}$ in the parent rock;

$I_{\text {weathered }}$ the content of an immobile element $I$ in the lateritic profile;

$I_{\text {parent }}$ : the content of $I$ in the parent rock (Nesbitt et al. 1979).

For the mass balance calculations, two references of parent rocks were considered, the clayey bauxite horizon and the claystone of the Itapecuru Formation (Pantoja 2015). Isocon diagrams were applied to graphically identify mobile and immobile elements precisely in the bauxite horizon, using the contents of $\mathrm{TiO}_{2}$ and $\mathrm{Al}_{2} \mathrm{O}_{3}$ and $\mathrm{Zr}$ as low mobility reference, according to Grant (1986) and Meyer et al. (2002). 

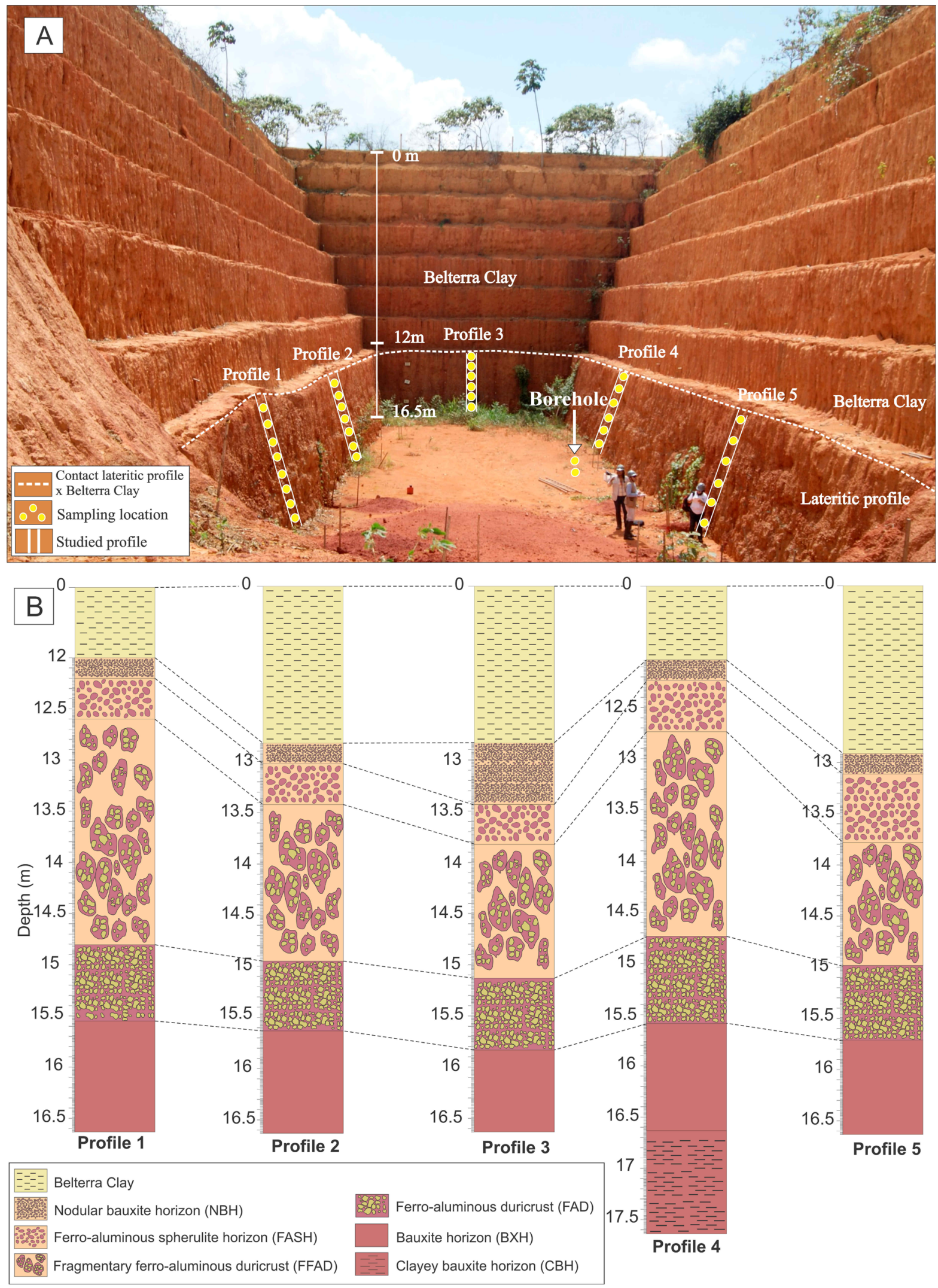

0
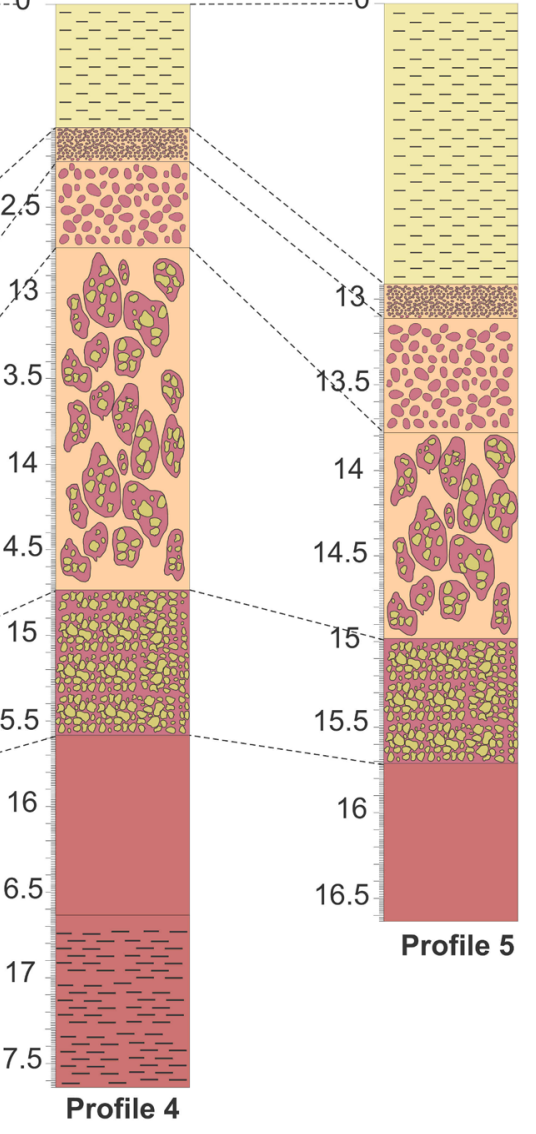

Profile 5

Figure 2. (A) Décio pilot mine, indicating the position of the profiles selected for sampling. (B) The succession of horizons from the Décio lateritic profile.

\section{RESULTS}

\section{Mineralogy and macromorphology}

From the bottom to the top, the Décio bauxite-bearing lateritic profile is composed of the following horizons: clayeybauxite $(\mathrm{CBH})$; bauxite $(\mathrm{BXH})$; ferro-aluminous duricrust (FAD); fragmentary ferro-aluminous duricrust (FFAD); ferro-aluminous spherulites (FASH); and nodular bauxite (NBH). The lateritic succession is overlaid by a yellowish homogeneous clayey cover, equivalent to the geological unit known as the Belterra Clay (Fig. 2B). 
The $\mathrm{CBH}$ comprises a mass of friable reddish clay (kaolinite + hematite), surrounding millimetric light pink nodules (gibbsite) (Figs. 3A and 4). The overlying BXH and FAD are compact and comprised of ocher yellow to red spherulites (goethite + hematite) gathered by a pinkish to reddish matrix (gibbsite + hematite). The matrix is more abundant in the $\mathrm{BXH}$ than in the $\mathrm{FAD}$, which is dominated by spherulites (Figs. 3B, $3 \mathrm{C}$ and 4$)$. The FFAD comprises disconnected blocks equivalent to the underlying $\mathrm{FAD}$, up to $20 \mathrm{~cm}$ in diameter and embedded in reddish clay matrix (Figs. 3D and 4).

The FFAD is covered in wavy contact by the FASH, dominated by brownish-red loose spherulites up to $2 \mathrm{~cm}$ in diameter (hematite + gibbsite), embedded in light red clay. Next, the
FASH is overlapped in wavy contact by the $\mathrm{NBH}$, characterized by irregular nodules up to $3 \mathrm{~cm}$ in diameter (gibbsite), embedded in a yellowish-brown clay (Figs. 3E and 4). Finally, the Belterra Clay covers the NBH, in wavy contact, with an average thickness of $12 \mathrm{~m}$, represented by homogeneous sandy clay, reddish-yellow at the bottom and ocher yellow towards the top (Fig. 3F).

\section{Micromorphology}

In the $\mathrm{BXH}$, the spherulites are internally zoned, as their cores are composed of hematite and their borders are formed of goethite. Both core and border present angular shape microcavities, occasionally filled with gibbsite crystals (Figs. 5A and
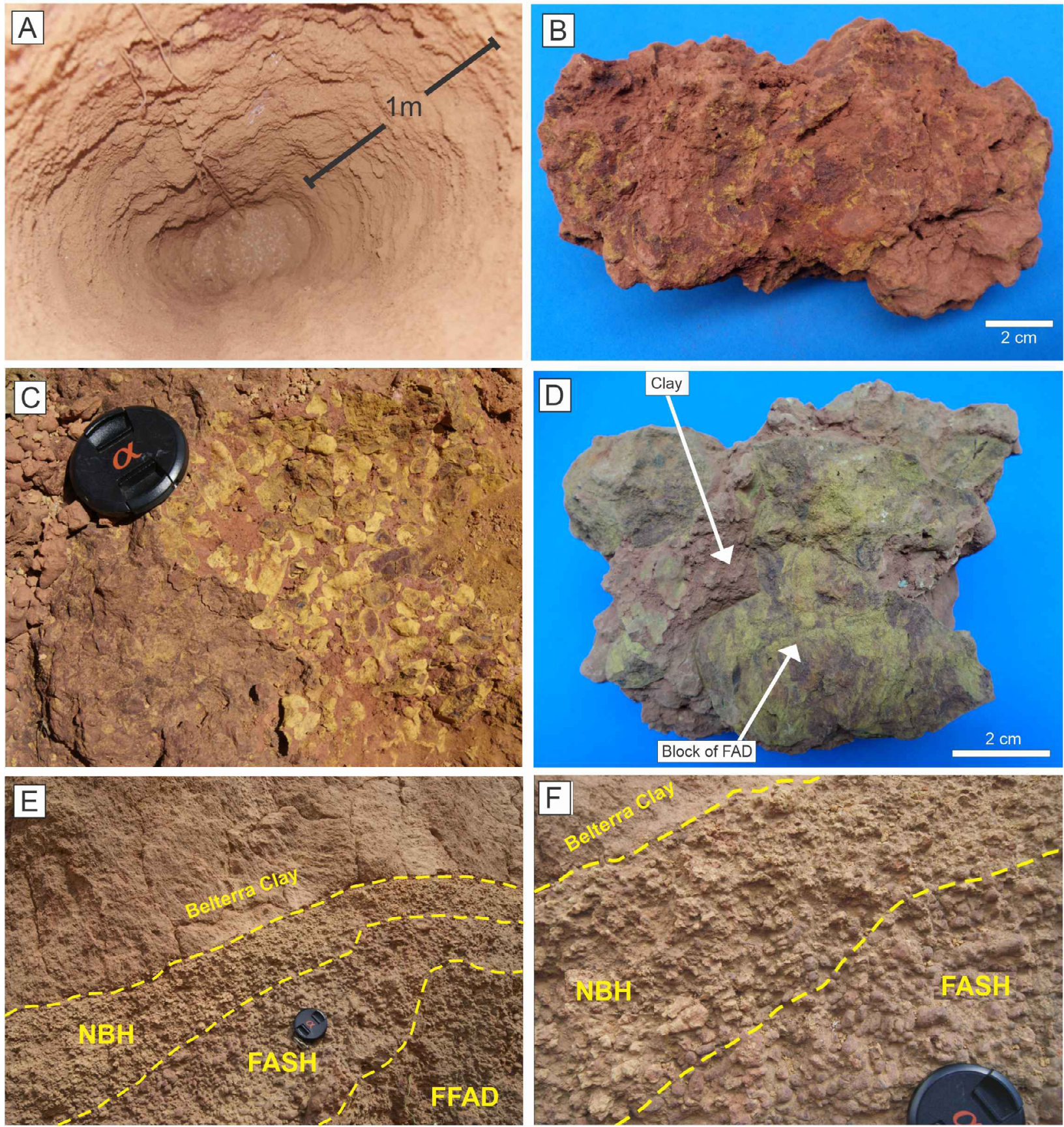

Figure 3. (A) The CBH outcropping in a borehole at the bottom of the Décio pilot mine, from 16.6 to $17.6 \mathrm{~m}$ deep. (B) The typical framework of the $\mathrm{BXH}$, showing the domain of reddish cement. (C) Outcrop of the FAD, highlighting the domain of ocher yellow spherulites. (D) A typical sample of the FFAD, which is represented by blocks of FAD embedded in red clay. (E and F) Wavy contact between FFAD, FASH, NBH horizons and the Belterra Clay. 


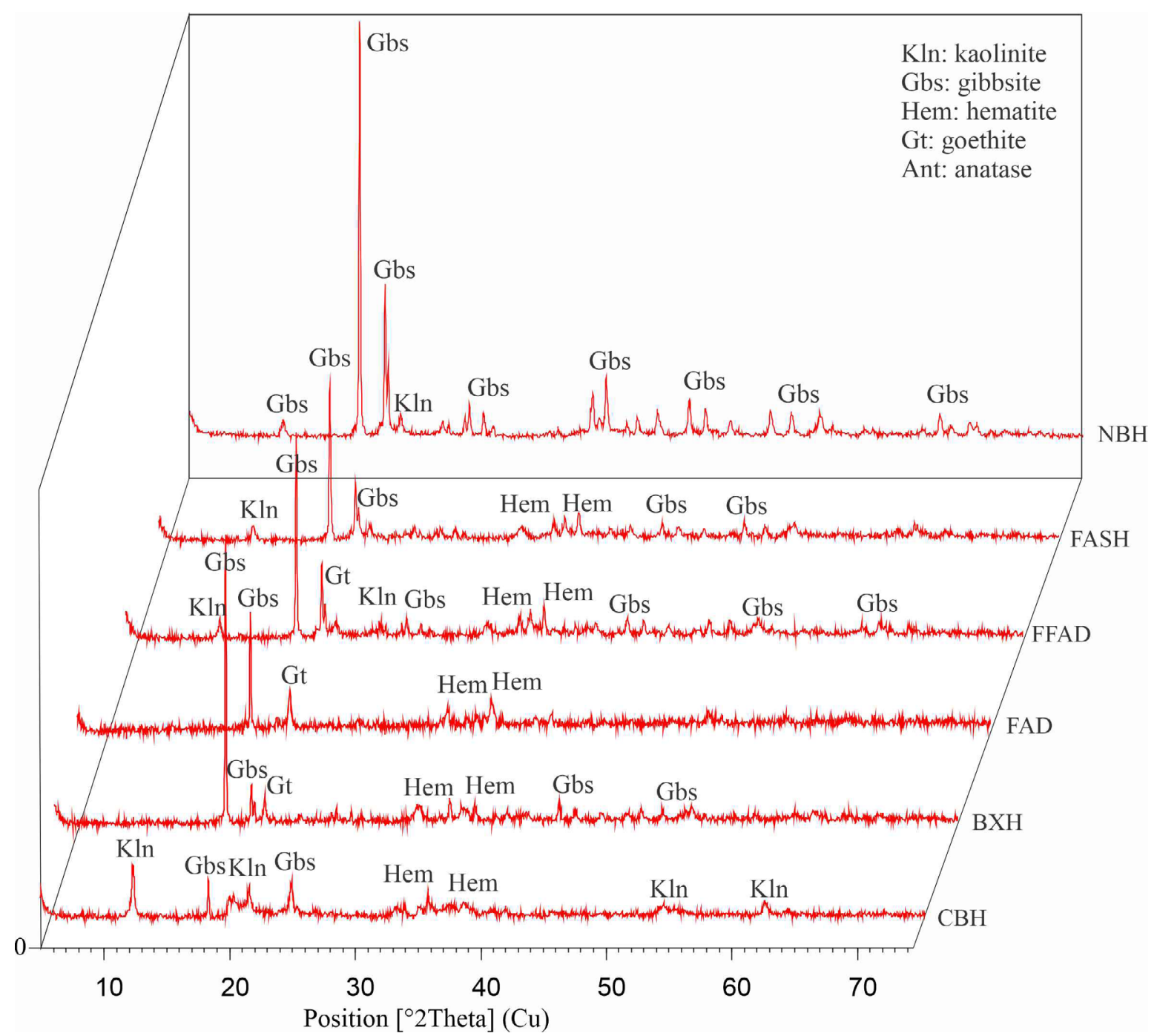

Figure 4. Mineralogical composition of the horizons of the Décio lateritic profile.

$5 B)$. In addition, the spherulites are cemented by a mass of cryptocrystalline goethite and hematite, crosscut by irregular veinlets of microcrystalline gibbsite (Fig. 5C). The framework of the FAD is also composed of spherulites with cores of hematite and borders of goethite. However, the mass that cements the spherulites is more abundant and exhibits more gibbsite veinlets in the $\mathrm{BXH}$ than in the $\mathrm{FAD}$ (Fig. 5D).

In the FASH, spherulites are composed of a ferro-aluminous mass (hematite and gibbsite), rich in irregular microcavities, partially filled with twinned pseudohexagonal gibbsite crystals, usually less than $100 \mu \mathrm{m}$ (Fig. 5E). The NBH comprises irregularly shaped nodules, showing the dominance of a yellowish mass of cryptocrystalline gibbsite. This mass is crosscut by a network of irregular veinlets composed of mesocrystalline gibbsite (Fig. 5F). As previously mentioned, the spherulites of the FASH and the nodules of the $\mathrm{HBN}$ are not embedded in the ferro-aluminous mass described in the $\mathrm{BXH}$ and $\mathrm{FAD}$, but in a clay matrix.

\section{Heavy minerals}

The horizons of the Décio lateritic profile present considerable amounts of zircon, tourmaline, rutile and kyanite. The first three minerals were found in the $250-125 \mu \mathrm{m}$ and $125-63 \mu \mathrm{m}$ fractions and are known to be ultra-stable, which is compatible with their association with lateritic products. On the other hand, kyanite is present only in the $250-125 \mu \mathrm{m}$ fraction.

Most of the zircon crystals and grains are colorless, although some can be yellow or brown; with low sphericity, variable degree of roundness and no evidence of corrosion (Fig. 6A). Tourmaline grains are predominantly greenish, but it is possible to occasionally see brownish, yellow and bluish grains. Most tourmalines are rounded and spherical, however some are elongated, with convex ends. In contrast, rutile grains are elongated, prismatic, and brownish-red. This association of ultra-stable heavy minerals shows substantial similarity throughout the profile (Fig. 6B). Kyanite was identified only in the $\mathrm{NBH}$, as colorless to yellowish cleavable tabular crystals. Nascimento and Góes (2007) identified a similar mineral association (tourmaline, zircon, rutile and kyanite, in addition to staurolite) in the quartz-sandstone from the Itapecuru Formation.

\section{Geochemistry}

\section{Major elements}

The Décio lateritic profile is composed mainly of $\mathrm{Al}_{2} \mathrm{O}_{3}$, $\mathrm{SiO}_{2}, \mathrm{Fe}_{2} \mathrm{O}_{3}, \mathrm{TiO}_{2}$ and LOI, with substantial oscillation from 

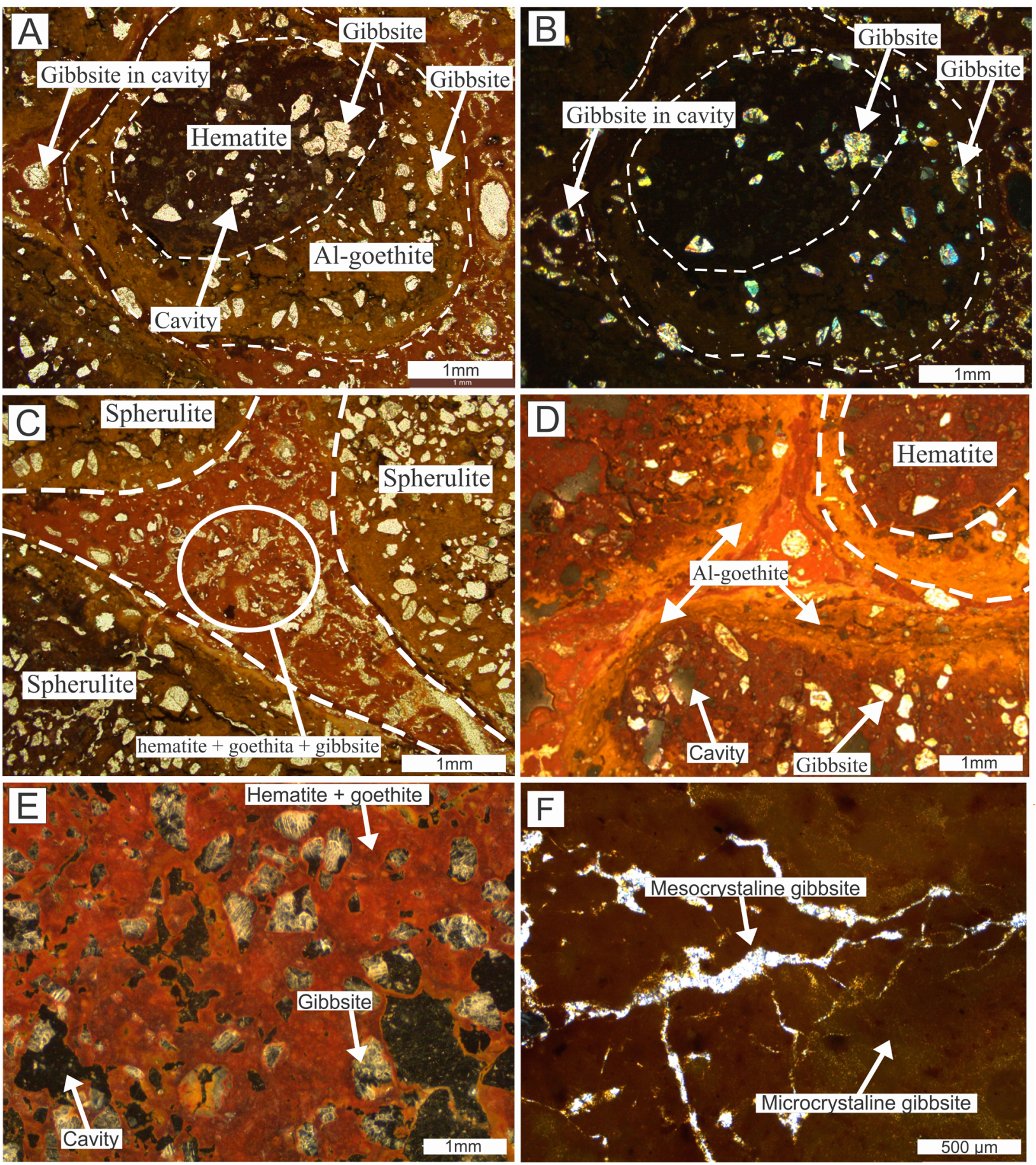

Figure 5. (A) Spherulite from the BXH, with the hematite core and goethite border and (B) crossed nicols. Mass of iron oxi-hydroxide with gibbsite veinlets, cementing the spherulites from the (C) BXH and (D) FAD. (E) The internal constitution of the spherulites from the FASH: gibbsite crystals embedded in a mass of hematite and goethite. (F) Nodules from the NBH showing a gibbsite mass crosscut by veinlets of mesocrystalline gibbsite. Transmitted light with (A, C, D and F) parallel nicols and (B and E) crossed nicols.

one horizon to another (Tab. 1), which point to two zones with opposite chemical behavior. From 17.7 to $13.7 \mathrm{~m}$ deep ( $\mathrm{CBH}, \mathrm{BXH}, \mathrm{FAD}, \mathrm{FFAD}), \mathrm{Fe}_{2} \mathrm{O}_{3}$ contents increase and $\mathrm{SiO}_{2}$ decreases from the bottom to the top. Contrarily, from 13.7 to $12 \mathrm{~m}$ deep (FASH $+\mathrm{NBH}), \mathrm{Fe}_{2} \mathrm{O}_{3}$ shows a substantial reduction coupled with $\mathrm{SiO}_{2}$ increase (Figs. 7A and 7B). Aluminum presents two high content zones and, therefore, two bauxite horizons ( $\mathrm{BXH}$ and NBX). The $\mathrm{TiO}_{2}$ contents (around 2.3\% in the $\mathrm{CBH}$ ) are higher at the base than in the overlying horizons ( 0.6 to $1.3 \%$ ) and the contents of $\mathrm{MgO}$, $\mathrm{K}_{2} \mathrm{O}, \mathrm{MnO}$ and $\mathrm{P}_{2} \mathrm{O}_{5}$ are below $0.05 \%$.
The variation of the contents of the major elements reflects the substantial mineralogical zoning (Fig. 8). At the base of the profile $(\mathrm{CBH})$, kaolinite is the most abundant mineral, with lower gibbsite and iron oxi-hydroxide. The intermediary section (BXH, FAD and FFAD) is dominated by gibbsite and iron oxi-hydroxides, with subordinated kaolinite. In the upper part (FASH and $\mathrm{NBH}$ ), there is a goethite and hematite decrease while gibbsite prevails, mainly distributed in nodules and spherulites. At the top, there is also an increase in kaolinite contentas in the FFAD, FASH and NBH's, blocks, spherulites and nodules, respectively, are embedded in the kaolinite 


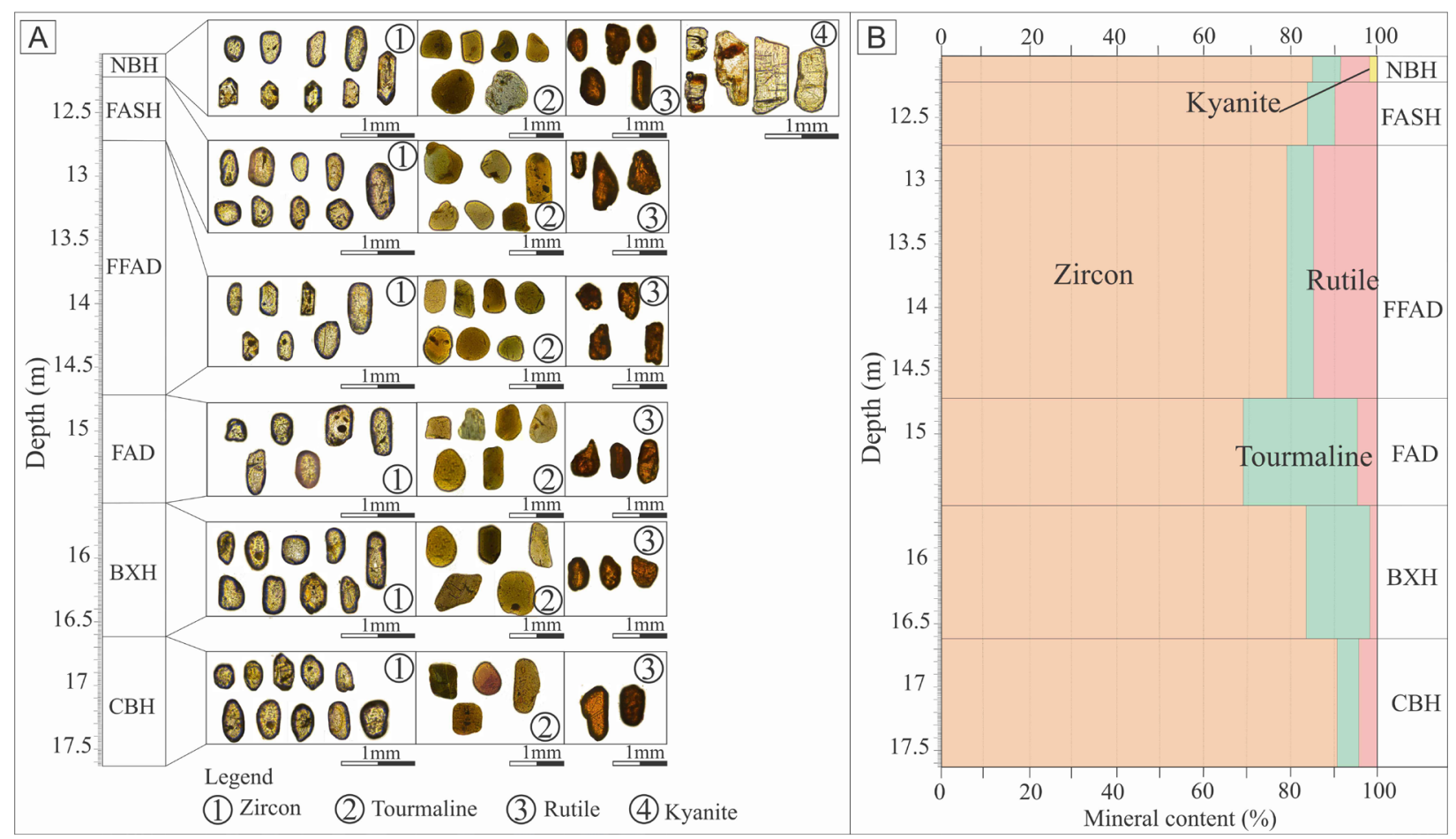

Figure 6. (A) Zircon, tourmaline, rutile and kyanite grains identified in the Décio lateritic profile. (B) Proportions of heavy minerals, obtained through counting grains under the optical microscope.

Table 1. Major and trace composition of the Décio bauxite-bearing lateritic profile compared to the average composition of the Upper Continental Crust.

\begin{tabular}{|c|c|c|c|c|c|c|c|c|c|c|c|c|c|}
\hline \multirow{3}{*}{ Elements } & \multirow{2}{*}{\multicolumn{2}{|c|}{$\begin{array}{c}\begin{array}{c}\text { CBH } \\
\text { bauxítica }\end{array} \\
\begin{array}{c}\text { Profile } \\
4\end{array}\end{array}$}} & \multicolumn{2}{|c|}{$\begin{array}{l}\text { BXH } \\
\text { maciça }\end{array}$} & \multicolumn{2}{|c|}{$\begin{array}{c}\text { FAD } \\
\text { ferro-luminosa }\end{array}$} & \multicolumn{2}{|c|}{$\begin{array}{c}\text { FFAD } \\
\text { desmantelada }\end{array}$} & \multicolumn{2}{|c|}{$\begin{array}{c}\text { FASH } \\
\text { ferruginosos }\end{array}$} & \multicolumn{2}{|c|}{ NBH } & \multirow{3}{*}{ UCC } \\
\hline & & & \multirow{2}{*}{$\begin{array}{c}\text { Profile } \\
3 \\
16.25 \mathrm{~m}\end{array}$} & \multirow{2}{*}{$\begin{array}{c}\begin{array}{c}\text { Profile } \\
4\end{array} \\
16.1 \mathrm{~m}\end{array}$} & \multirow{2}{*}{$\begin{array}{c}\text { Profile } \\
3 \\
15.5 \mathrm{~m}\end{array}$} & \multirow{2}{*}{$\begin{array}{c}\text { Profile } \\
4 \\
15.1 \mathrm{~m}\end{array}$} & \multirow{2}{*}{$\begin{array}{c}\text { Profile } \\
3 \\
14.45 \mathrm{~m}\end{array}$} & \multirow{2}{*}{$\begin{array}{c}\text { Profile } \\
4 \\
13.7 \mathrm{~m}\end{array}$} & \multirow{2}{*}{$\begin{array}{c}\begin{array}{c}\text { Profile } \\
3\end{array} \\
13.6 \mathrm{~m}\end{array}$} & \multirow{2}{*}{$\begin{array}{c}\text { Profile } \\
4\end{array}$} & \multirow{2}{*}{$\begin{array}{c}\text { Profile } \\
3 \\
13.1 \mathrm{~m}\end{array}$} & \multirow{2}{*}{$\begin{array}{c}\begin{array}{c}\text { Profile } \\
4\end{array} \\
12.1 \mathrm{~m}\end{array}$} & \\
\hline & $17.6 \mathrm{~m}$ & $16.7 \mathrm{~m}$ & & & & & & & & & & & \\
\hline \multicolumn{14}{|l|}{ Weight $\%$} \\
\hline $\mathrm{SiO}_{2}$ & 31.37 & 29.56 & 2.27 & 3.59 & 3.19 & 3.42 & 11.20 & 7.21 & 9.76 & 10.57 & 6.39 & 6.58 & 66.6 \\
\hline $\mathrm{Al}_{2} \mathrm{O}_{3}$ & 34.60 & 35.45 & 44.38 & 38.69 & 24.97 & 28.23 & 21.44 & 20.68 & 47.84 & 37.35 & 57.25 & 57.44 & 15.4 \\
\hline $\mathrm{Fe}_{2} \mathrm{O}_{3}$ & 14.89 & 16.12 & 27.59 & 34.24 & 52.15 & 48.75 & 50.59 & 55.58 & 15.75 & 29.91 & 4.85 & 4.85 & 5.04 \\
\hline $\mathrm{TiO}_{2}$ & 2.37 & 2.30 & 1.31 & 0.83 & 0.67 & 0.83 & 0.74 & 0.64 & 1.18 & 0.96 & 1.14 & 1.15 & 0.64 \\
\hline $\mathrm{MnO}$ & 0.02 & 0.03 & 0.01 & nd & nd & nd & 0.01 & nd & nd & 0.02 & nd & nd & 0.1 \\
\hline $\mathrm{MgO}$ & 0.01 & 0.01 & nd & nd & nd & nd & nd & nd & nd & nd & nd & nd & 2.48 \\
\hline $\mathrm{K}_{2} \mathrm{O}$ & 0.02 & 0.02 & nd & nd & nd & nd & nd & nd & nd & nd & nd & nd & 2.80 \\
\hline $\mathrm{P}_{2} \mathrm{O}_{5}$ & 0.05 & 0.05 & 0.02 & nd & nd & 0.02 & nd & nd & nd & nd & nd & nd & 0.15 \\
\hline LOI & 16.4 & 16.2 & 24.2 & 22.4 & 18.7 & 18.5 & 15.6 & 15.4 & 25.3 & 20.9 & 30.2 & 29.8 & - \\
\hline Total & 99.73 & 99.74 & 99.78 & 99.75 & 99.69 & 99.75 & 99.57 & 99.51 & 99.83 & 99.69 & 99.83 & 99.82 & - \\
\hline \multicolumn{14}{|l|}{ ppm } \\
\hline $\mathrm{Be}$ & nd & 1 & nd & 2 & nd & 1 & nd & 1 & nd & nd & 3 & nd & 2.1 \\
\hline Sc & 16 & 16 & 11 & 9 & 18 & 14 & 32 & 24 & 12 & 26 & 8 & 9 & 14.0 \\
\hline $\mathrm{V}$ & 261 & 284 & 408 & 418 & 908 & 554 & 1429 & 1743 & 314 & 663 & 102 & 103 & 97 \\
\hline $\mathrm{Cr}$ & 171 & 185 & 164 & 157 & 212 & 212 & 705 & 500 & 240 & 493 & 144 & 144 & 92 \\
\hline Co & 1.7 & 1.2 & 2.9 & 2.0 & 2.3 & 1.0 & 3.0 & 2.0 & 2.4 & 6.2 & 3.5 & 8.3 & 17.3 \\
\hline $\mathrm{Ni}$ & 1.4 & 2.4 & 0.6 & 0.4 & 0.9 & 0.7 & 1.0 & 1.3 & 0.5 & 1.6 & 0.3 & 0.4 & 47 \\
\hline $\mathrm{Cu}$ & 3.4 & 6.1 & 5.0 & 5.0 & 13.6 & 8.7 & 25.5 & 15.0 & 4.7 & 38.0 & 0.8 & 1.0 & 28 \\
\hline $\mathrm{Zn}$ & 3 & 3 & 2 & 2 & 6 & 4 & 8 & 7 & 1 & 9 & nd & nd & 193 \\
\hline $\mathrm{Ga}$ & 53.4 & 54.5 & 51.4 & 42.5 & 43.9 & 41.7 & 88.4 & 68.2 & 49.7 & 77.1 & 39.9 & 40.3 & 17.5 \\
\hline
\end{tabular}


Table 1. Continuation.

\begin{tabular}{|c|c|c|c|c|c|c|c|c|c|c|c|c|c|}
\hline \multirow{3}{*}{ Elements } & \multirow{2}{*}{\multicolumn{2}{|c|}{$\begin{array}{c}\text { CBH } \\
\text { bauxítica } \\
\text { Profile } \\
4 \\
\end{array}$}} & \multicolumn{2}{|c|}{$\begin{array}{c}\mathbf{B X H} \\
\text { maciça }\end{array}$} & \multicolumn{2}{|c|}{$\begin{array}{c}\text { FAD } \\
\text { ferro-luminosa }\end{array}$} & \multicolumn{2}{|c|}{$\begin{array}{c}\text { FFAD } \\
\text { desmantelada }\end{array}$} & \multicolumn{2}{|c|}{$\begin{array}{c}\text { FASH } \\
\text { ferruginosos }\end{array}$} & \multicolumn{2}{|c|}{ NBH } & \multirow{3}{*}{ UCC } \\
\hline & & & \multirow{2}{*}{$\begin{array}{c}\text { Profile } \\
3 \\
16.25 \mathrm{~m}\end{array}$} & \multirow{2}{*}{$\begin{array}{c}\begin{array}{c}\text { Profile } \\
4\end{array} \\
16.1 \mathrm{~m}\end{array}$} & \multirow{2}{*}{$\begin{array}{c}\text { Profile } \\
3 \\
15.5 \mathrm{~m}\end{array}$} & \multirow{2}{*}{$\begin{array}{c}\begin{array}{c}\text { Profile } \\
4\end{array} \\
15.1 \mathrm{~m}\end{array}$} & \multirow{2}{*}{$\begin{array}{c}\text { Profile } \\
3 \\
14.45 \mathrm{~m} \\
\end{array}$} & \multirow{2}{*}{$\begin{array}{c}\begin{array}{c}\text { Profile } \\
4\end{array} \\
13.7 \mathrm{~m}\end{array}$} & \multirow{2}{*}{$\begin{array}{c}\begin{array}{c}\text { Profile } \\
3\end{array} \\
13.6 \mathrm{~m}\end{array}$} & \multirow{2}{*}{$\begin{array}{c}\text { Profile } \\
4 \\
12.45 \mathrm{~m}\end{array}$} & \multirow{2}{*}{$\begin{array}{c}\begin{array}{c}\text { Profile } \\
3\end{array} \\
13.1 \mathrm{~m}\end{array}$} & \multirow{2}{*}{$\begin{array}{c}\begin{array}{c}\text { Profile } \\
4\end{array} \\
12.1 \mathrm{~m}\end{array}$} & \\
\hline & $17.6 \mathrm{~m}$ & $16.7 \mathrm{~m}$ & & & & & & & & & & & \\
\hline As & 1.6 & 1.8 & 6.2 & 6.2 & 11.9 & 7.3 & 8.3 & 8.1 & 8.4 & 7.6 & 1.0 & 1.1 & 4.8 \\
\hline $\mathrm{Se}$ & nd & nd & nd & 0.6 & nd & nd & nd & nd & nd & nd & nd & nd & 0.09 \\
\hline $\mathrm{Rb}$ & 0.5 & 0.5 & nd & $<0.1$ & nd & nd & nd & nd & nd & 0.2 & nd & nd & 84 \\
\hline $\mathrm{Sr}$ & 57.6 & 74.3 & 35.8 & 20.1 & 15.4 & 18.5 & 10.7 & 7.9 & 11.0 & 13.0 & 11.2 & 12.6 & 320 \\
\hline $\mathrm{Y}$ & 28.5 & 27.1 & 16.4 & 12.7 & 8.4 & 10.0 & 15.4 & 10.1 & 15.0 & 17.5 & 12.3 & 13.0 & 21 \\
\hline $\mathrm{Zr}$ & 964 & 904 & 639 & 484 & 340 & 384 & 503 & 402 & 671 & 561 & 545 & 554 & 193 \\
\hline $\mathrm{Nb}$ & 46.4 & 43.1 & 25.1 & 15.5 & 12.8 & 15.6 & 15.3 & 12.7 & 24.2 & 20.3 & 21.5 & 23.8 & 12 \\
\hline Mo & 0.7 & 0.9 & 1.4 & 1.3 & 2.1 & 1.6 & 4.1 & 3.3 & 1.7 & 2.7 & 0.2 & 0.3 & 1.1 \\
\hline $\mathrm{Ag}$ & nd & nd & nd & 0.2 & 0.4 & 0.3 & 0.7 & 0.5 & 0.4 & 0.3 & 0.1 & nd & 0.053 \\
\hline Sn & 8 & 7 & 4 & 2 & 2 & 3 & 3 & 2 & 3 & 5 & 4 & 4 & 2.1 \\
\hline $\mathrm{Sb}$ & 0.2 & 0.3 & 0.7 & 0.6 & 1.0 & 0.7 & 1.7 & 1.7 & 1.0 & 1.3 & 0.1 & 0.1 & 0.4 \\
\hline Cs & 0.1 & nd & nd & nd & nd & nd & nd & nd & nd & nd & nd & nd & 4.9 \\
\hline $\mathrm{Ba}$ & 69 & 91 & 43 & 21 & 17 & 21 & 12 & 12 & 13 & 13 & 11 & 12 & 624 \\
\hline $\mathrm{Hf}$ & 24.8 & 24.3 & 16.7 & 12.1 & 9.0 & 10.1 & 12.9 & 10.5 & 16.3 & 14.2 & 13.9 & 13.4 & 5.3 \\
\hline $\mathrm{Ta}$ & 3.1 & 3.2 & 1.8 & 1.2 & 1.0 & 1.3 & 1.3 & 0.9 & 1.7 & 1.4 & 1.7 & 1.5 & 0.9 \\
\hline $\mathrm{W}$ & 4.2 & 3.6 & 5.7 & 2.6 & 1.9 & 2.8 & 2.0 & 1.3 & 3.4 & 3.2 & 2.6 & 2.8 & 1.9 \\
\hline $\mathrm{Au}$ & nd & nd & nd & nd & 0.6 & nd & 1.5 & nd & 1.1 & nd & nd & 0.9 & 0.0015 \\
\hline $\mathrm{Hg}$ & 0.04 & 0.05 & 0.07 & 0.10 & 0.45 & 0.25 & 0.43 & 0.58 & 0.21 & 0.31 & 0.09 & 0.11 & 0.05 \\
\hline $\mathrm{Pb}$ & 7.8 & 10.1 & 10.3 & 8.2 & 11.5 & 10.0 & 20.9 & 17.3 & 6.6 & 20.3 & 1.1 & 1.2 & 17 \\
\hline $\mathrm{Bi}$ & 0.4 & 0.4 & 0.4 & 0.3 & 0.3 & 0.3 & 0.7 & 0.5 & 0.6 & 0.7 & 0.1 & 0.2 & 0.16 \\
\hline Th & 45.2 & 44.2 & 34.6 & 30.0 & 34.0 & 31.8 & 50.2 & 47.7 & 35.3 & 46.4 & 21.7 & 22.4 & 10.5 \\
\hline $\mathrm{U}$ & 3.8 & 4.0 & 2.5 & 1.9 & 3.2 & 3.1 & 7.9 & 5.6 & 2.7 & 6.5 & 2.3 & 2.2 & 2.7 \\
\hline $\mathrm{La}$ & 71.2 & 92.4 & 56.3 & 30.6 & 24.1 & 29.0 & 20.4 & 15.3 & 14.3 & 21.2 & 13.9 & 14.1 & 31 \\
\hline $\mathrm{Ce}$ & 102.8 & 135.5 & 65.2 & 35.9 & 25.6 & 30.7 & 30.6 & 16.3 & 24.6 & 47.4 & 22.3 & 23.4 & 63 \\
\hline $\operatorname{Pr}$ & 9.53 & 12.01 & 5.74 & 3.13 & 2.63 & 3.07 & 3.41 & 2.00 & 2.10 & 3.96 & 1.91 & 2.01 & 7.1 \\
\hline $\mathrm{Nd}$ & 26.4 & 33.6 & 15.8 & 9.2 & 7.9 & 8.3 & 11.5 & 6.7 & 6.6 & 14.8 & 5.5 & 6.4 & 27 \\
\hline $\mathrm{Sm}$ & 3.57 & 5.03 & 2.16 & 1.27 & 1.28 & 1.26 & 2.84 & 1.30 & 1.36 & 3.42 & 1.01 & 1.17 & 4.7 \\
\hline $\mathrm{Eu}$ & 0.81 & 1.05 & 0.46 & 0.29 & 0.26 & 0.27 & 0.61 & 0.30 & 0.36 & 0.77 & 0.25 & 0.27 & 1.0 \\
\hline $\mathrm{Gd}$ & 3.98 & 4.78 & 2.35 & 1.50 & 1.22 & 1.42 & 2.66 & 1.43 & 1.69 & 3.42 & 1.39 & 1.39 & 4.0 \\
\hline $\mathrm{Tb}$ & 0.74 & 0.79 & 0.43 & 0.28 & 0.23 & 0.26 & 0.48 & 0.27 & 0.34 & 0.60 & 0.29 & 0.30 & 0.7 \\
\hline Dy & 4.96 & 4.91 & 3.00 & 1.84 & 1.43 & 1.94 & 3.14 & 1.95 & 2.70 & 3.62 & 2.04 & 2.25 & 3.9 \\
\hline Ho & 1.08 & 1.08 & 0.64 & 0.48 & 0.33 & 0.41 & 0.66 & 0.39 & 0.60 & 0.79 & 0.45 & 0.50 & 0.83 \\
\hline $\mathrm{Er}$ & 3.68 & 3.59 & 2.05 & 1.54 & 1.11 & 1.36 & 2.29 & 1.35 & 2.07 & 2.78 & 1.79 & 1.74 & 2.3 \\
\hline $\mathrm{Tm}$ & 0.61 & 0.60 & 0.37 & 0.28 & 0.19 & 0.22 & 0.32 & 0.24 & 0.35 & 0.41 & 0.30 & 0.31 & 0.3 \\
\hline $\mathrm{Yb}$ & 4.55 & 4.30 & 2.68 & 1.86 & 1.49 & 1.73 & 2.45 & 1.77 & 2.70 & 2.91 & 2.26 & 2.18 & 1.96 \\
\hline $\mathrm{Lu}$ & 0.74 & 0.67 & 0.43 & 0.30 & 0.24 & 0.25 & 0.37 & 0.27 & 0.37 & 0.44 & 0.36 & 0.37 & 0.31 \\
\hline Ho & 1.08 & 1.08 & 0.64 & 0.48 & 0.33 & 0.41 & 0.66 & 0.39 & 0.60 & 0.79 & 0.45 & 0.50 & 0.83 \\
\hline Er & 3.68 & 3.59 & 2.05 & 1.54 & 1.11 & 1.36 & 2.29 & 1.35 & 2.07 & 2.78 & 1.79 & 1.74 & 2.3 \\
\hline $\mathrm{Tm}$ & 0.61 & 0.60 & 0.37 & 0.28 & 0.19 & 0.22 & 0.32 & 0.24 & 0.35 & 0.41 & 0.30 & 0.31 & 0.3 \\
\hline $\mathrm{Yb}$ & 4.55 & 4.30 & 2.68 & 1.86 & 1.49 & 1.73 & 2.45 & 1.77 & 2.70 & 2.91 & 2.26 & 2.18 & 1.96 \\
\hline $\mathrm{Lu}$ & 0.74 & 0.67 & 0.43 & 0.30 & 0.24 & 0.25 & 0.37 & 0.27 & 0.37 & 0.44 & 0.36 & 0.37 & 0.31 \\
\hline$\sum$ REE & 235 & 300 & 160 & 88 & 68 & 80 & 82 & 50 & 60 & 107 & 54 & 56 & 112 \\
\hline
\end{tabular}

Source of UCC data: Rudnick and Gao (2003). 

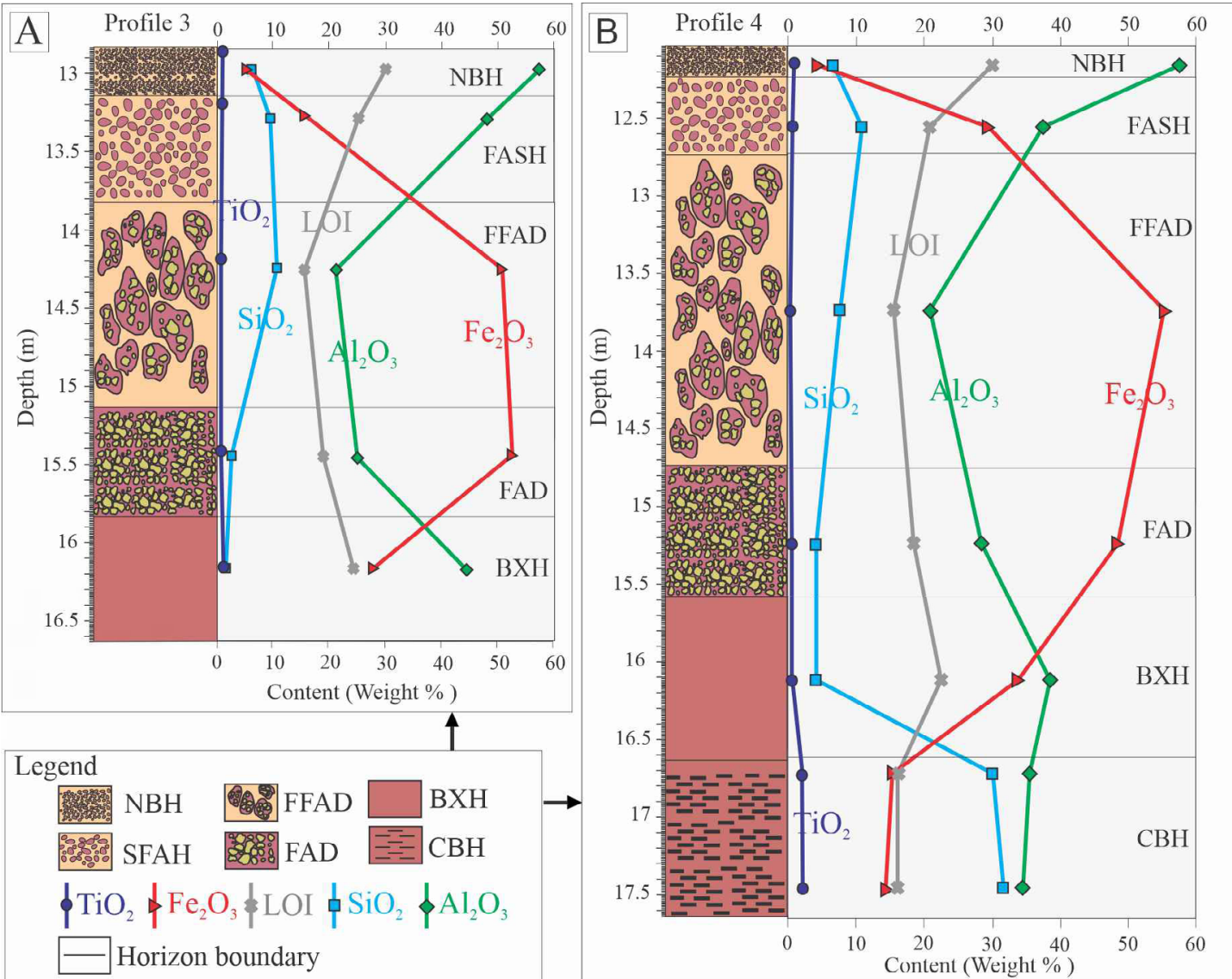

Figure 7. Vertical distribution of major elements across Décio horizons, based on (A) profile 3 and (B) profile 4.

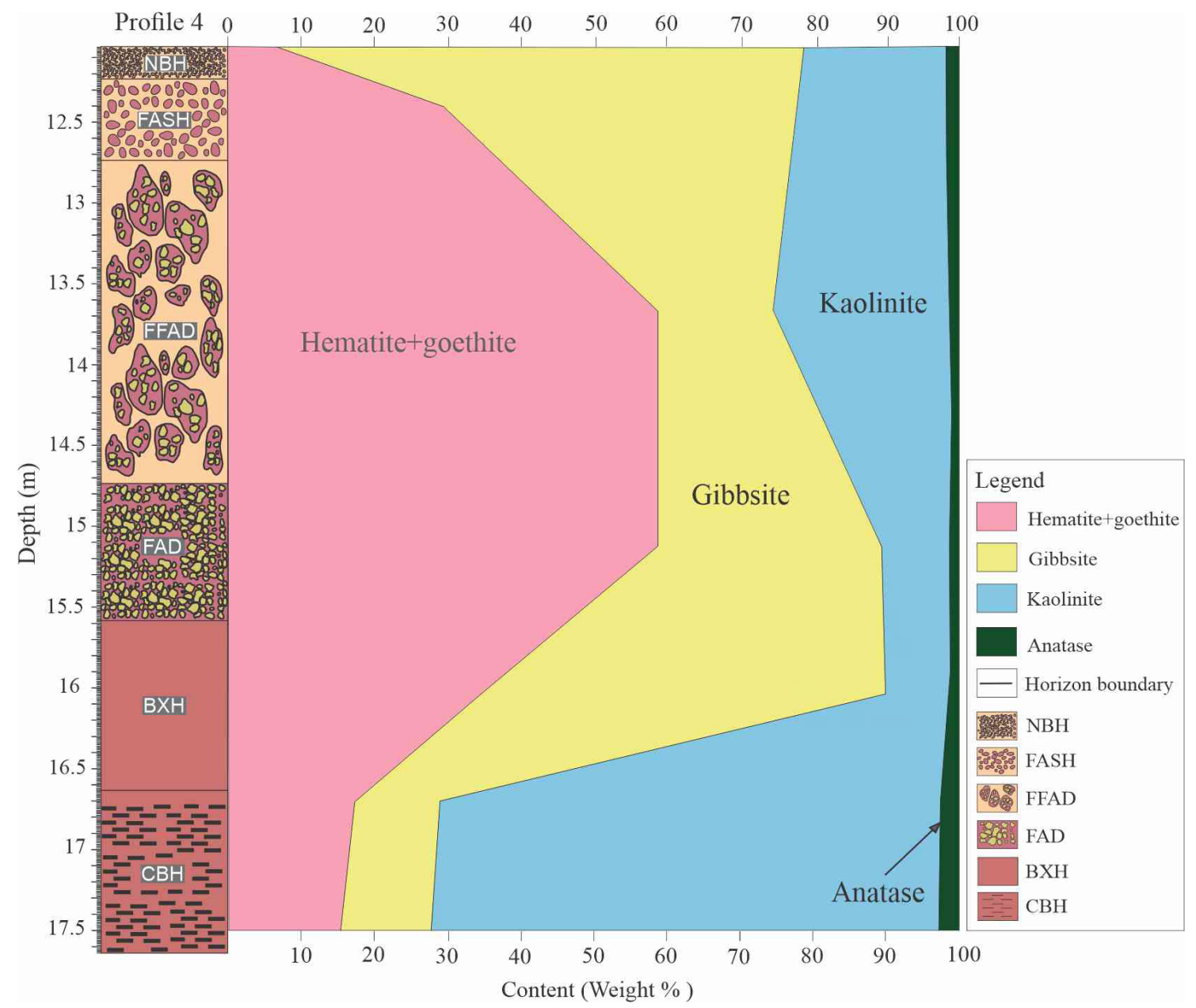

Figure 8. Vertical distribution of minerals across the Décio horizons obtained through stoichiometric calculations. 
matrix. On the other hand, the anatase contents fluctuate from the base to the top of the profile.

\section{Trace elements}

The trace elements distribution often reflects the mineralogical composition (Tab. 1). Barium, Hf, Nb, Rb, Sn, Ta, Th, $\mathrm{U}, \mathrm{Y}, \mathrm{Pb}$ and $\mathrm{REE}$ are higher in the $\mathrm{CBH}$ when compared to the other horizons, on account of the higher amount of zircon. On the other hand, $\mathrm{Cr}, \mathrm{Ga}, \mathrm{Sc}, \mathrm{V}, \mathrm{Hg}, \mathrm{Mo}, \mathrm{Cu}$ and $\mathrm{Sb}$ show higher concentrations in the $\mathrm{FAD}$ and $\mathrm{FFAD}$, which present higher amounts of iron oxi-hydroxides. Scandium, Sn, Th, $\mathrm{U}, \mathrm{Bi}$ and $\mathrm{Ni}$, exhibit a substantial decrease in the FASH and $\mathrm{NBH}$ compared to the other horizons since both are poor in goethite and hematite.

On average, gallium concentrations are three times higher than the UCC (17.5 ppm), as verified by Mordberg (1993); exhibiting a weak negative correlation with $\mathrm{Al}_{2} \mathrm{O}_{3}(\mathrm{r}=-0.54)$ and contrasting with some other bauxites (Bárdossy and Aleva 1990, Ling et al. 2020), but remaining in accordance with Hieronymus et al. (2001). Chromium contents, which range from 210 to $1,030 \mathrm{ppm}$ (much higher than the UCC), conform to data from Hill et al. (2000) and Bárdossy and Aleva (1990), who have pointed to the enrichment of Cr in lateritic profiles. Yttrium contents are higher than UCC only in the $\mathrm{CBH}$ (28.5 ppm) and range from 8.4 to $17.5 \mathrm{ppm}$ in the overlying horizons, conformed to Mordberg (1993).

The trace elements normalized to the UCC show substantial similarity across the profile, indicating little fractionation between the horizons, with just a moderate variation in the NBH (Fig. 9A). However, groups of elements with similar behavior can be identified. The concentrations of $\mathrm{Co}$, $\mathrm{Ni}, \mathrm{Cu}, \mathrm{Zn}, \mathrm{Rb}, \mathrm{Sr}$ and $\mathrm{Ba}$ are below the UCC in all the horizons or even below the detection limit (Be, Cs, $\mathrm{Ag}$ and $\mathrm{Au}$ ). Nevertheless, concentrations of V, Cr, Ga, Zr, Hf, Ta, W, Hg, $\mathrm{Bi}$, Th and $\mathrm{U}$ are invariably above the UCC. Finally, Sc, As, Y, $\mathrm{Nb}, \mathrm{Mo}, \mathrm{Sn}, \mathrm{Sb}, \mathrm{REE}, \mathrm{Pb}$ concentrations can be below or above UCC, depending on the horizon analyzed.

Most of the horizons present concentrations of $\mathrm{V}, \mathrm{Co}$, As, $\mathrm{Mo}, \mathrm{Sc}, \mathrm{Sb}, \mathrm{Hg}$ and $\mathrm{Bi}$ five to ten times higher than the $\mathrm{CBH}$ and $\mathrm{Zr}$, Hf, Nb, Ta, Y and REE lower (Fig. 9B). This behavior contrasts with the $\mathrm{NBH}$, which is below the $\mathrm{CBH}$ for all elements, except for Co. The similarity between the distribution in patterns of the trace elements is highlighted when they are normalized to the Itapecuru claystone (Figs. 9B and 9C), demonstrating some compatibility between the $\mathrm{CBH}$ and the Itapecuru Formation.

The $\Sigma$ REE values are fluctuating across the profile and are in average three times higher than the UCC in the $\mathrm{CBH}$ $(\Sigma E T R=234,65$ and $300.31 \mathrm{ppm})$ and half the UCC in the $\mathrm{NBH}(\Sigma \mathrm{REE}=53.75 \mathrm{ppm}$ and $56.39 \mathrm{ppm})$. Therefore, this data demonstrates a decrease from the bottom to the top.

When the REE are normalized to the chondrites data, all of the horizons present parallel behavior, with insignificant fractionation between the horizons and enrichment of LREE in comparison to HREE (Fig. 10A). The same behavior is verified after the Itapecuru claystone normalization, which also presents a strong negative anomaly in Ce (Fig. 10B). However,
REE normalized to the $\mathrm{CBH}$ data exhibits an opposite distribution pattern, with slight enrichment in HREE compared to the LREE (Fig. 10C).

\section{Mass balance}

The loss and gain of chemical elements during the formation of the $\mathrm{BXH}$ were graphically estimated through isocon diagrams, testing the composition of the $\mathrm{CBH}$, Itapecuru claystone (Pantoja 2015) and UCC (Rudnick and Gao 2003) as references from the parent rock. When the $\mathrm{CBH}$ is considered, the elements plotted on the isocon (immobile elements) are Tm, Tb, Ni, Lu, Eu, Ho, Dy, U, Zn, Gd, Ta, Sm, Er, Y, Co, Zn, W, Sc, Hf, Y, Nd, Th, Ga, La and Ce, in addition to $\mathrm{TiO}_{2}, \mathrm{Al}_{2} \mathrm{O}_{3}$ and $\mathrm{Zr}$, which are already expected (Gu et al. 2013). Most of these elements exhibit a strong positive correlation with $\mathrm{Zr}$ and $\mathrm{TiO}_{2}$, and therefore with zircon and anatase (Fig. 11A). This group of immobile elements is the same as when the Itapecuru claystone is considered the parent rock (Fig. 11B). However, it is partially different from those found when the UCC is used as reference. In this case, $\mathrm{Bi}, \mathrm{Sb}, \mathrm{Mo}$, As and V are also plotted on the isocon (Fig. 11C).

The mass balance calculation shows that the depletion of $\mathrm{SiO}_{2}$ in the $\mathrm{BXH}$ ranges from -61.5 to $-89.8 \%$ for the $\mathrm{CBH}$ as a parent rock (Fig. 12A) and from -63.69 to $-95.44 \%$ concerning the Itapecuru claystone (Fig. 13A). The $\mathrm{Fe}_{2} \mathrm{O}_{3}$ contents show loss of mass in the NBH $(-80.4 \%)$ and gain in the other horizons $(+105.6 \%$ in $\mathrm{BXH},+301.3 \%$ in $\mathrm{FAD},+524.5 \%$ in $\mathrm{FFAD}$ and $+86,1 \%$ in $\mathrm{FASH})$, relative to $\mathrm{CBH}$ as parent rock. However, in comparison to the Itapecuru claystone, the profile is enriched in $\mathrm{Fe}_{2} \mathrm{O}_{3}(+2.3 \%$ in $\mathrm{CBH},+110.37 \%$ in $\mathrm{BXH}$, $+310.50 \%$ in $\mathrm{FAD},+538.87 \%$ in $\mathrm{FFAD}$ and $+90.36 \%$ in $\mathrm{FASH})$.

Considering the $\mathrm{CBH}$ as parent rock, the Décio lateritc profile is enriched in $\mathrm{Cr}_{2} \mathrm{O}_{3}, \mathrm{~V}$, As, Mo and $\mathrm{Cu}$, except in the $\mathrm{NBH}$. The horizons also exhibit gain of $\mathrm{Sc}, \mathrm{Co}, \mathrm{Ni}, \mathrm{Zn}$ and $\mathrm{Ga}$, except in the BXH and NBX (Figs. 12B-12H). However, Sr, Y, $\mathrm{Zr}, \mathrm{Nb}, \mathrm{Sn}, \mathrm{Ba}, \mathrm{Hf}, \mathrm{Ta}, \mathrm{W}, \mathrm{Pb}$ and REE are lost across the lateritic succession. This pattern is very similar to the Itapecuru claytone based mass balance, except for the behavior of Co, $\mathrm{Ni}, \mathrm{Ga}, \mathrm{Sr}, \mathrm{W}, \mathrm{Pb}$, Th, U and LREE, which are variable according to the analyzed horizon (Figs. 13B-13H).

\section{DISCUSSION}

\section{Mineral evolution and major elements}

The $\mathrm{CBH}$ evolves toward the top to form gibbsite nodules embedded in kaolinite, then forming form the BXH and composing the typical zoning of lateritic profiles (Tardy 1997). The presence of spherulites is the most highlighting aspect of the Décio lateritic profile. Successive lateritization cycles and surficial reworking are suggested by spherulites internally composed of smaller ones, also embedded in a ferro-aluminous mass (e.g., Salamab-Ellahi et al. 2019). The high porosity of the spherulites of the BXH, FAD, FFAD and FASH was originated from the hydrolysis of clay minerals from the parent rock (likely the Itapecuru Formation claystone). The mass of hematite, Al-goethite, gibbsite; and the gibbsite mesocrystals 


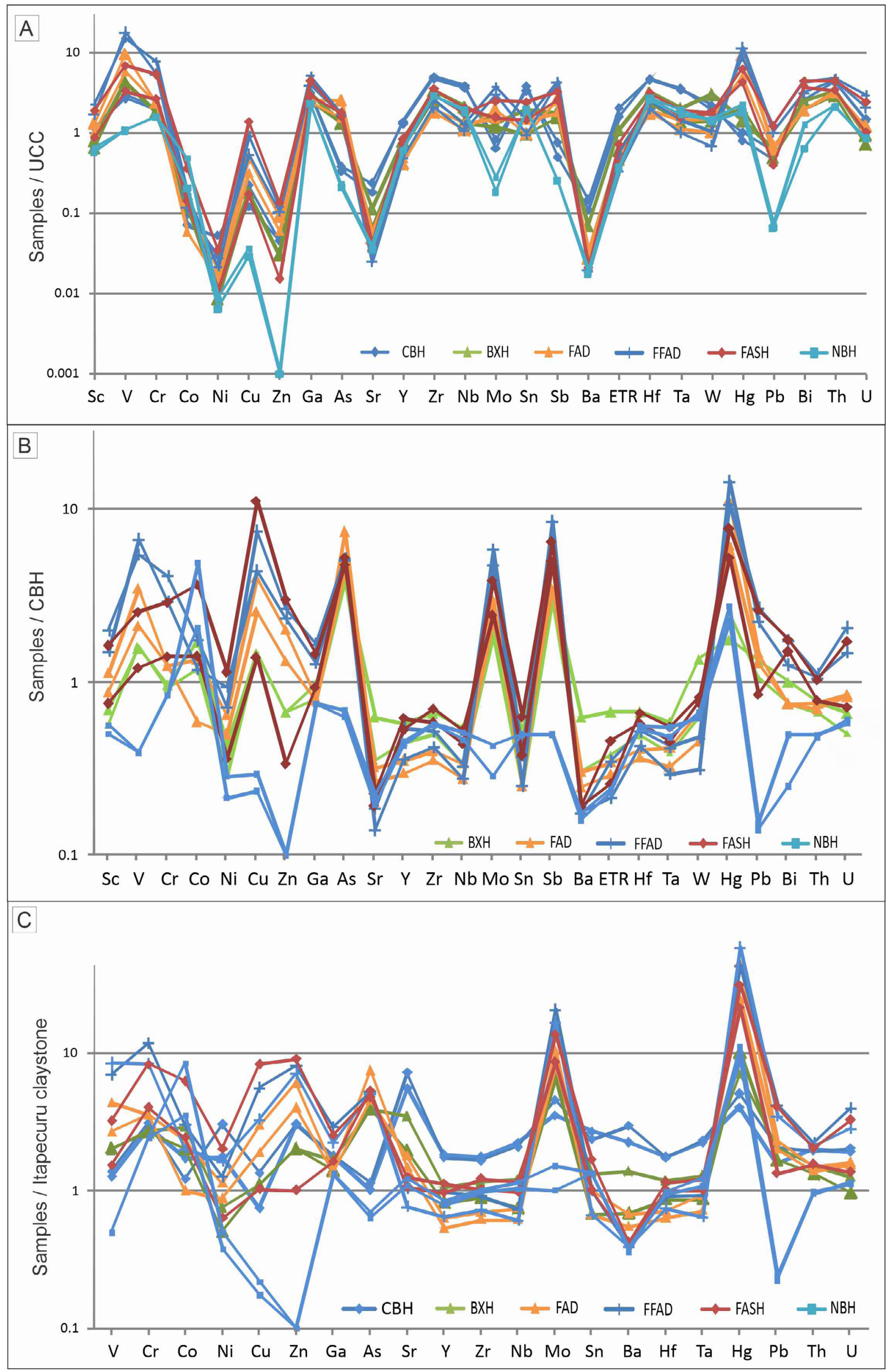

Figure 9. (A) Trace elements in the Décio lateritic bauxite profile normalized to the UCC data (Rudnick and Gao 2003); (B) to the chemical composition of the $\mathrm{CBH}$; (C) to the Itapecuru claystone data after Pantoja (2015). 

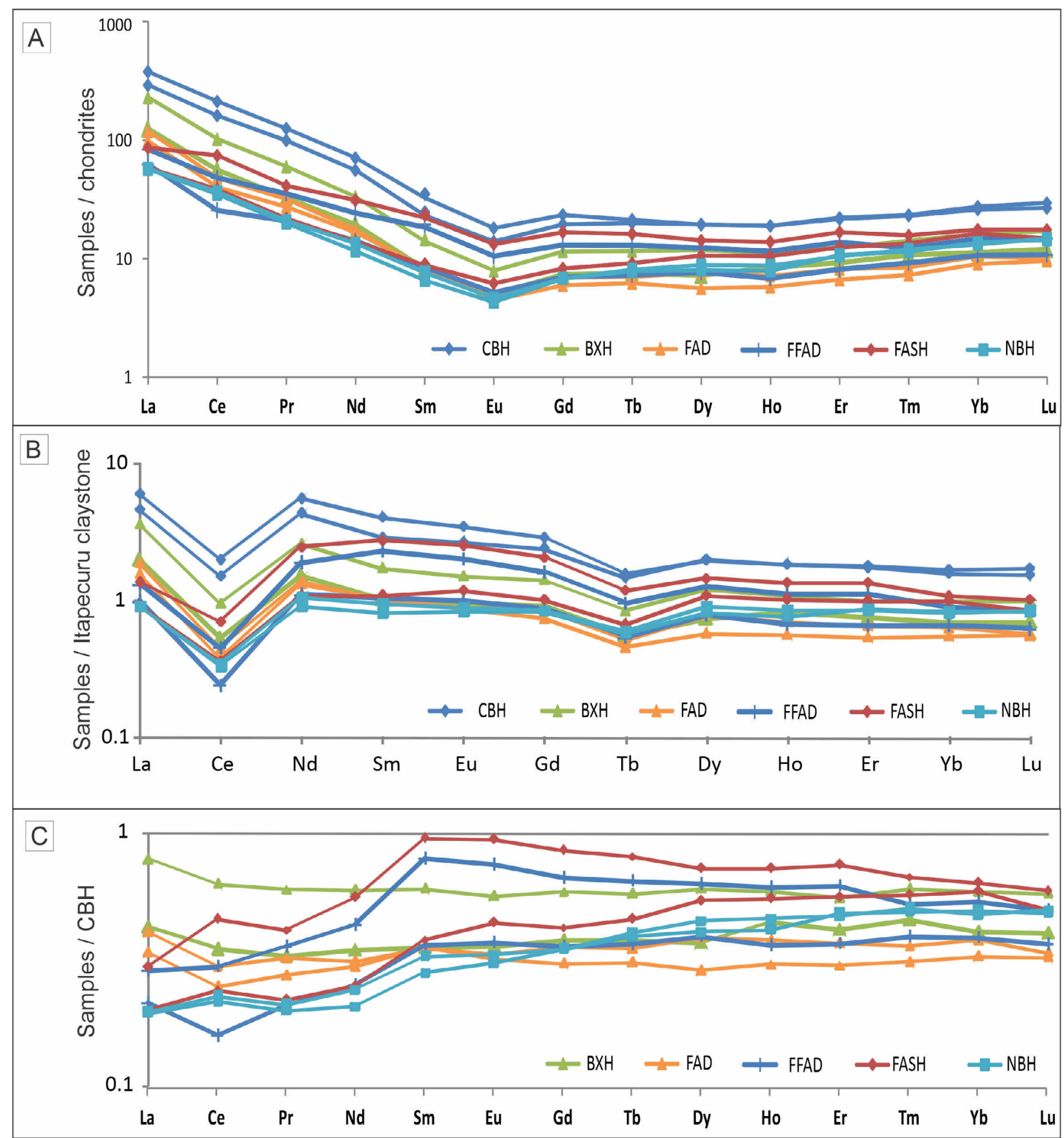

Figure 10. Distribution of REE concentrations in the Décio lateritic bauxite profile normalized (A) to the chondrites from Evensen $e$ al. (1978); (B) to the chemical composition of the Itapecuru claystone according to Pantoja (2015); (C) to the chemical composition of the CBH.

which partially fill the cavities demonstrate some aluminum mobility across the profile (e.g., Monsels and Van Bergen 2017).

The degradation of the FAD to form the FFAD indicates that after consolidation, the lateritic products started a new cycle of reorganization, marked by partial subjection to weathering, as demonstrated in the Paragominas and Juruti deposits (e.g., Kotschoubey et al. 2005), indicating the intensification of warm and humid conditions and the development of a rainforest (Costa 1991). Under the new climatic conditions, the goethite borders formed around the spherulites, mainly in the BXH, FAD and FFAD (e.g., Horbe and Anand 2011).

The increase of $\mathrm{Fe}_{2} \mathrm{O}_{3}$ contents from the base to the top $(\mathrm{CBH}, \mathrm{BXH}$ and $\mathrm{FAD})$ is typical of the complete lateritic profiles (e.g., Diko et al. 2001). However, the abrupt decrease in $\mathrm{Fe}_{2} \mathrm{O}_{3}$ verified in the FFAD, FASH and $\mathrm{NBH}$ is not accordant with a classic lateritic evolution. Furthermore, the behavior of $\mathrm{Al}_{2} \mathrm{O}_{3}$ is also different from the classic laterites, as the Décio profile presents two distinct zones of high $\mathrm{Al}_{2} \mathrm{O}_{3}$ contents ( $\mathrm{BXH}$ and NBX). These chemical behaviors, in addition to the textural features, points out the post-lateritic reorganization, characterized by lateral movement of lateritic materials under drier conditions (e.g., Horbe and Anand 2011). Thus, the lower horizons might be the first products of lateritization, while the upper ones are derived from surficial reworking.

The behavior of $\mathrm{Fe}_{2} \mathrm{O}_{3}$ and $\mathrm{Al}_{2} \mathrm{O}_{3}$ is concordant to most bauxite-bearing lateritic profiles of the Amazon, 

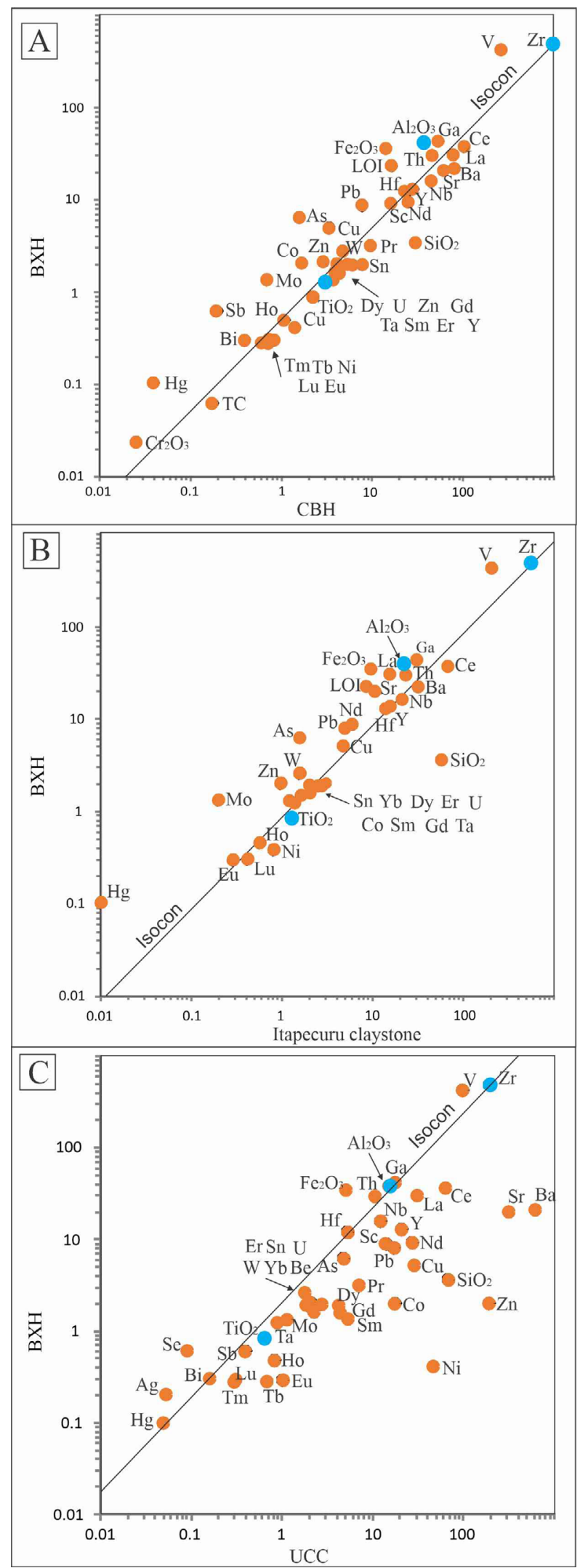

Figure 11. Isocon diagrams (Grant 1986) comparing the main composition of the (A) Décio bauxite (BXH) with the $\mathrm{CBH}$; (B) Itapecuru claystone (Pantoja 2015); (C) the UCC (Rudnick and Gao 2003). $\mathrm{Al}_{2} \mathrm{O}_{2}, \mathrm{TiO}_{2}, \mathrm{Fe}_{2} \mathrm{O}_{3}, \mathrm{SiO}_{2}, \mathrm{Cr}_{2} \mathrm{O}_{3}$ and LOI are presented in Wt. \%; trace elements are expressed in ppm.

such as Paragominas, Trombetas and Juruti (Boulangé and Carvalho 1997, Costa et al. 2014, Lima 2018). Furthermore, as commonly verified in lateritic profiles (Bárdossy 1982, Radusinović et al. 2017), the LOI reflects the variable domain of gibbsite, in addition to kaolinite and goethite, behaving similarly to $\mathrm{Al}_{2} \mathrm{O}_{3}$.

The decrease in the $\mathrm{TiO}_{2}$ content from the base $(\mathrm{CBH})$ to the top (BXH, FAD, FFAD, FASH, NBH) points out the heterogeneity of the parent rock since anatase and rutile are stable under weathering, since they would be supposed to accumulate from the base to the top if the protolith were homogeneous (Henderson 1984, Linnen et al. 2005). Moreover, the allochthonous nature of FASH and $\mathrm{NBH}$ might partially explain this vertical oscillation. The contents of $\mathrm{MgO}, \mathrm{K}_{2} \mathrm{O}$, $\mathrm{MnO}$ and $\mathrm{P}_{2} \mathrm{O}_{5}$ in Décio are very low, below $0.05 \%$, a common attribute in most of the Amazon's lateritic bauxite profiles (Costa et al. 2014).

According to the chemical classification of laterites proposed by Bárdossy (1982), the Décio lateritic profile comprises clayey bauxite, bauxite, ferric bauxite, low iron bauxite and bauxite ferrite (Fig. 14). The degree of lateritization, based on the Schellmann (1983) classification, is moderate in the $\mathrm{CBH}$ and strong in the overlying horizons (e.g., BXH, FAD, FFAD, FASH and NBH). In general, the intensity of lateritization increases upwards, except in FASH and $\mathrm{NBH}$, which confirms the $\mathrm{CBH}$ as an intermediary between the protolith and the bauxite, in accordance with Bárdossy (1982) and Radusinović et al. (2017).

Among major elements, the strongest (negative) correlation occurs between $\mathrm{Fe}_{2} \mathrm{O}_{3}$ and $\mathrm{Al}_{2} \mathrm{O}_{3}$ (Fig. 15A), which is a classic behavior in bauxite-bearing lateritic profiles (e.g., Valeton 1972, Monsels and Van Bergen 2017), reflecting the increase of hematite and goethite towards the top (especially in the $\mathrm{FAD}$ and FFAD), coupled with a relative decrease in gibbsite contents. On the other hand, there is no correlation between $\mathrm{Al}_{2} \mathrm{O}_{3}$ and $\mathrm{SiO}_{2}$ (Fig. 15B).

The vertical fluctuation of $\mathrm{TiO}_{2}$ contents point out the substantial faciological variation of the parent rock from the base to the top (Momo et al. 2020). This behavior suggests that the horizons have been formed from at least two different lithotypes or two different facies of the same lithotype. The first would have originated the $\mathrm{CBH}$, which presents $\mathrm{TiO}_{2}$ contents around 2.3\%, while the second would have originated the overlying horizons, with lower $\mathrm{TiO}_{2}$ contents, ranging from 0.64 to $1.31 \%$. On the other hand, the strong positive correlation between $\mathrm{Al}_{2} \mathrm{O}_{3} \mathrm{x}$ $\mathrm{TiO}_{2}$ demonstrates that, despite the heterogeneous distribution, $\mathrm{TiO}_{2}$ behaves as an immobile element (Fig. 15C).

\section{Behavior of the trace elements}

The strong positive correlations between $\mathrm{Fe}_{2} \mathrm{O}_{3}$ and $\mathrm{Mo}$, $\mathrm{As}, \mathrm{Pb}, \mathrm{Hg}, \mathrm{Sb}, \mathrm{Zn}, \mathrm{V}$ and $\mathrm{Sc}$ indicate their assimilation by hematite and/or goethite (Figs. 15D-15H). Vanadium concentrations are six times higher than the UCC. This enrichment is concordant to most bauxite deposits (Wang et al. 2012, Hanilçi 2013), where V is normally associated with Fe and Ti oxides (Ling et al. 2020). The positive correlation of $\mathrm{V}$ with $\mathrm{Fe}_{2} \mathrm{O}_{3}(\mathrm{r}=0.85), \mathrm{Cr}_{2} \mathrm{O}_{3}(\mathrm{r}=0.82)$, and $\mathrm{Sc}(\mathrm{r}=0.80)$, together with the weak correlation with $\mathrm{Ti}(\mathrm{r}=-0.55)$, reinforces that goethite and/or hematite are its main carriers (e.g., Mongelli et al. 2014).

Zirconium concentrations in the Décio profile range from 339 to $964 \mathrm{ppm}$. These values reflect the high degree of 

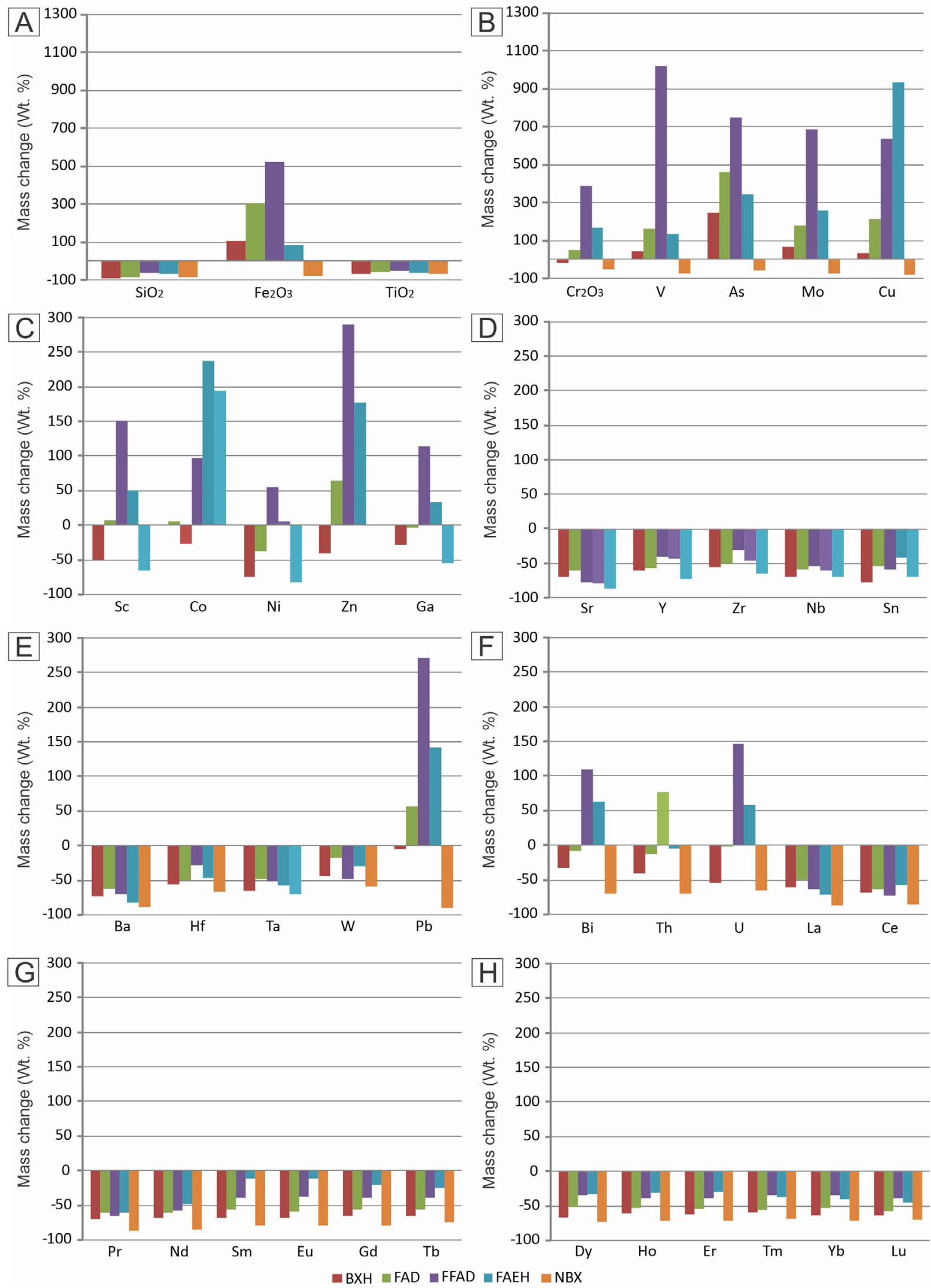

Figure 12. Mass balance of the $\mathrm{BXH}$, considering $\mathrm{Al}_{2} \mathrm{O}_{3}$ immobile and the $\mathrm{CBH}$ as a reference of the parent rock.

lateritization (Liu et al. 2013, Yuste et al. 2017). As in most bauxite deposits (e.g., Ling et al.2020), the positive correlation $\mathrm{Zr} \times \mathrm{Hf}(\mathrm{r}=0.99)$ is present. Additionally, the $\mathrm{Zr} / \mathrm{Hf}$ ratios range from 37.2 to 41.3 (Tab. 1), typical of zircons derived from protoliths of acidic to intermediate composition and/or metamorphic and sedimentary equivalents (Barros et al. 2005). The similar Zr / Hf values suggest that most zircon grains probably have the same provenance (e.g., Liu et al. 2013). These ratios are similar to those verified in the Belterra Clay and in bauxites from Juruti (Costa et al. 2014).

The decrease in $\Sigma \mathrm{REE}$, from the bottom to the topo, reflects the zircon's heterogeneous distribution, the main carrier of 

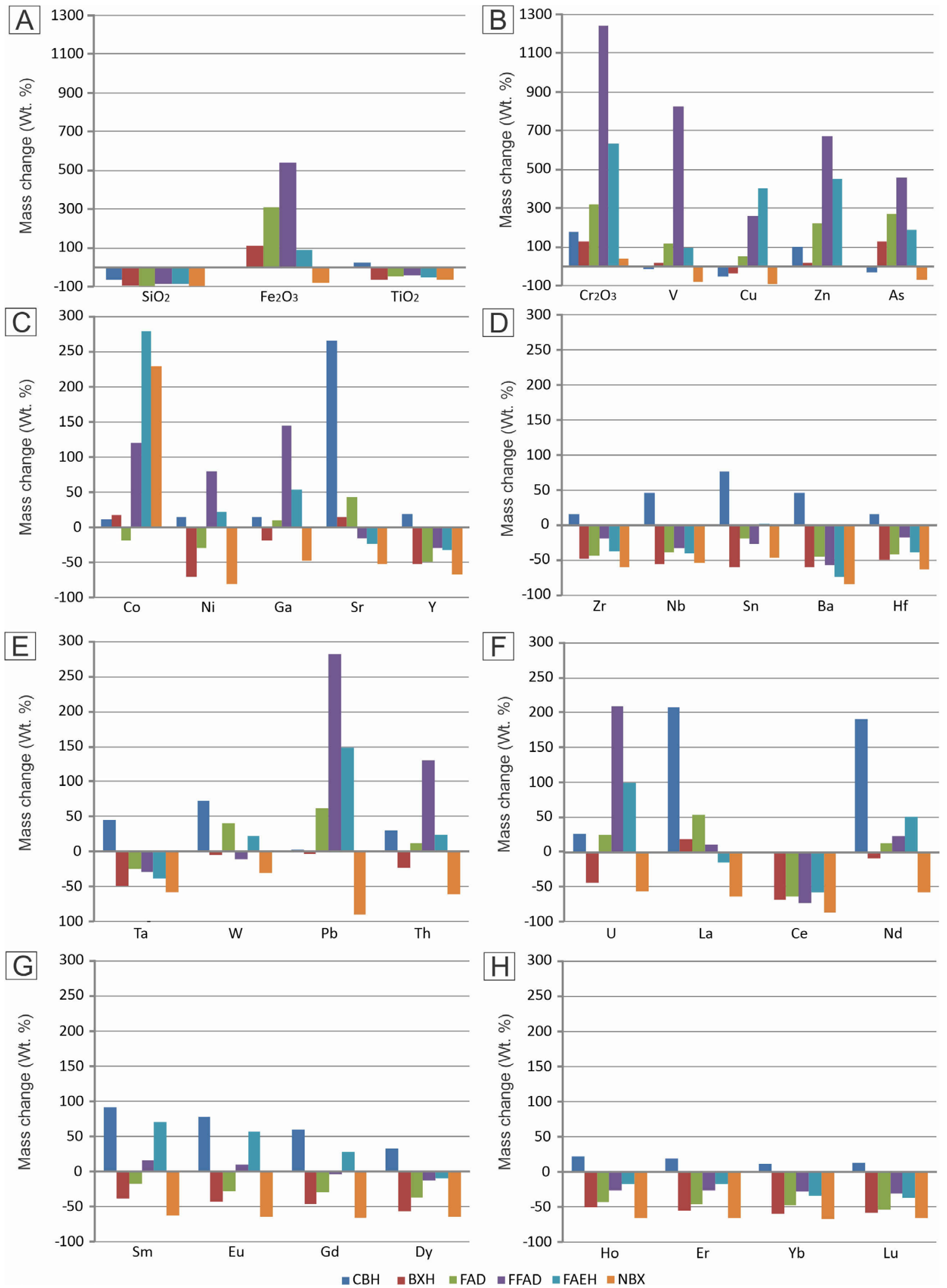

Figure 13. Mass balance of the $\mathrm{BXH}$, considering $\mathrm{Al}_{2} \mathrm{O}_{3}$ immobile and the Itapecuru claystone (Pantoja 2015) as a reference of the parent rock.

$\mathrm{REE}$, as indicated by the strong positive $\mathrm{Zr} \times \mathrm{x}$ RE correlation, commonly identified in lateritic profiles (e.g., Calagari and Abedini 2007) (Fig. 15I). Moreover, a mechanical reworking of zircon may also occur during the long-term evolution of lateritic profiles (e.g., Brimhall et al. 1988, Colin et al. 1992).

The positive linear correlation between $\mathrm{Zr}$ and $\mathrm{TiO}_{2}$ suggests that zircon, anatase and rutile have accumulated similarly across the profile (Fig. 15J), as demonstrated by the slight variations of the $\mathrm{TiO}_{2} / \mathrm{Zr}$ ratios (14.72 to 25.43). In addition to the linear distribution, the samples are distributed in two groups. The first group is represented by the $\mathrm{CBH}$ (which shows higher $\mathrm{Zr}$ contents) and the second is composed of the samples from the other horizons. 


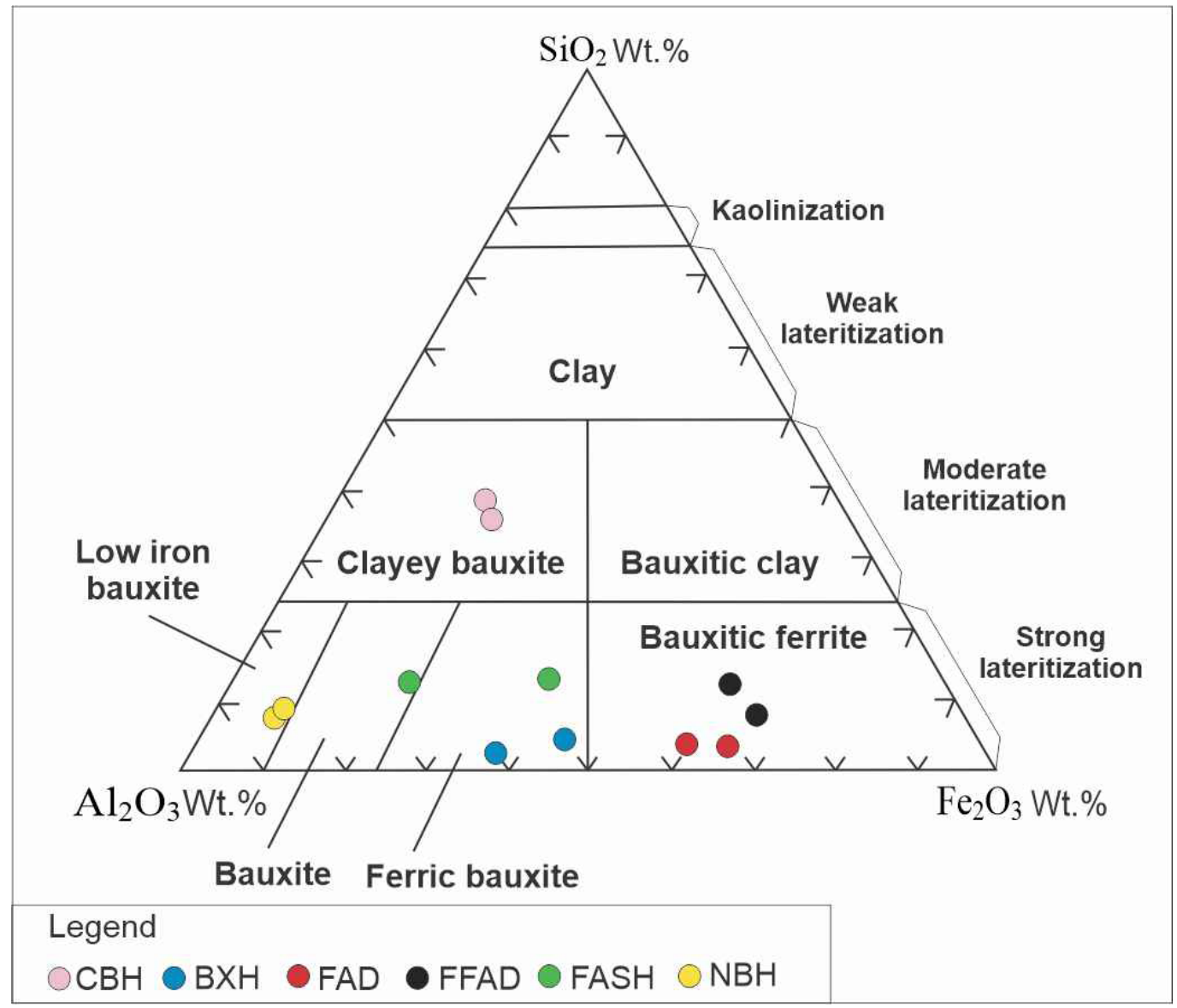

Figure 14. Classification of the Décio lateritic horizons based on $\mathrm{Fe}_{2} \mathrm{O}_{3}, \mathrm{SiO}_{2}$ and $\mathrm{Al}_{2} \mathrm{O}_{3}$ proportion, according to Bárdossy (1982). The right side of the ternary diagram presents the intensity of lateritization, according to Schellmann (1983).

Although the correlation between $\mathrm{Ga}_{\mathrm{Xe}} \mathrm{O}_{3}$ is moderate $(\mathrm{r}=0.42)$, Ga shows strong positive correlation with $\mathrm{Sc}$ $(\mathrm{r}=0.93), \mathrm{Mo}(\mathrm{r}=0.83), \mathrm{Pb}(\mathrm{r}=0.88)$ and $\mathrm{Zn}(\mathrm{r}=0.80)$. These elements present strong positive correlations with $\mathrm{Fe}_{2} \mathrm{O}_{3}$ and consequently with iron oxi-hydroxides. The negative correlation between $\mathrm{Gax}_{2} \mathrm{O}_{3}$ normally occurs due to the chemical reworking, which happens when previously formed kaolinite and gibbsite are hydrolyzed, disturbing the original correlation expected in laterites (Hieronymus et al. 2001).

Chromium presents moderate positive correlation with $\mathrm{Ni}$, as verified by McAlister and Smith (1997); and strong positive correlation with $\mathrm{Ga}(\mathrm{r}=0.94), \mathrm{Sc}(\mathrm{r}=9.94), \mathrm{U}(\mathrm{r}=0.95)$, $\mathrm{V}(\mathrm{r}=0.81)$, Mo $(\mathrm{r}=0.93)$ and $\mathrm{Cu}(\mathrm{r}=0.82)$. No affinity between $\mathrm{Y}$ and $\mathrm{Al}_{2} \mathrm{O}_{3}$ was found in the present study since the distribution is possibly restricted to the structure of zircon, as indicated by the strong $\mathrm{Zr} x \mathrm{Y}$ positive correlation $(\mathrm{r}=0.96)$. Niobium and Ta present a strong positive correlation with $\mathrm{TiO}_{2}(\mathrm{r}=0.99)$ (e.g., Liu et al. 2013, Hou et al. 2017), as well as with $\mathrm{Zr}(\mathrm{r}=0.97$ for $\mathrm{Zr} \times \mathrm{Nb}$; $\mathrm{r}=0.96$ for $\mathrm{Zr} \times \mathrm{Ta})$, suggesting similar accumulation of anatase and zircon across the profile, as newly formed and resistant mineral, respectively (e.g., Calagari and Abedini 2007, Zamanian et al. 2015).

\section{Gain and loss of mass}

The similarity between the isocon diagrams in Figs. 11A and $11 \mathrm{~B}$ demonstrates the substantial affinity between the $\mathrm{CBH}$ and the Itapecuru claystone, since both exhibit a slight enrichment in the elements that correlate with $\mathrm{Fe}_{2} \mathrm{O}_{3}$ (e.g., Mo, $\mathrm{As}, \mathrm{Pb}, \mathrm{Hg}, \mathrm{Sb}, \mathrm{Zn}, \mathrm{V}$ and $\mathrm{Sc}$ ), which are plotted to the left of the isocon. Both diagrams also indicate the low mobility of the elements that correlate with $\mathrm{TiO}_{2}$ and $\mathrm{Zr}$ (e.g., $\mathrm{Hf}, \mathrm{Nb}, \mathrm{Ta}, \mathrm{Y}$ and $\mathrm{REE}$ ), plotted to the right of the isocon. On the other hand, when the UCC composition is considered as a reference for the parent rock, the BXH is depleted of most elements analyzed (Fig. 11C).

The loss and gain of mass in the $\mathrm{BXH}$ are in accordance with the mineral transformations and the main chemical correlations presented in Figs. 12 and 13. The depletion of $\mathrm{SiO}_{2}$ in the $\mathrm{BXH}$ considering both the $\mathrm{CBH}$ and the Itapecuru claystone reflects the hydrolysis of the clay minerals to form the gibbsite. On the other hand, the strong enrichment in iron, regardless of the reference of the parent rock, suggests intense incorporation, as a result of its high mobility in the upper part of the profile (e.g., Kelepertsis 2002, Horbe and Anand 2011). The trace elements reinforce the affinity between the $\mathrm{CBH}$ and the Itapecuru claystone, as the losses and gains of $\mathrm{Cr}, \mathrm{V}$, $\mathrm{Cu}, \mathrm{Pb}, \mathrm{Zn}, \mathrm{Co}, \mathrm{Ni}, \mathrm{Ga}, \mathrm{Sr}, \mathrm{Zr}, \mathrm{Nb}, \mathrm{Sn}, \mathrm{Ba}, \mathrm{Hf}, \mathrm{Ta}, \mathrm{Th}, \mathrm{U}$ and $\mathrm{REE}$ are very similar when they are considered as parent rocks.

\section{CONCLUSIONS}

The lower horizons of the Décio lateritic profile display a classic lateritic succession, composed of clayey bauxite, bauxite and ferro-aluminous duricrust. In contrast, the upper horizons (e.i., fragmentary ferro-aluminous duricrust, ferro-aluminous spherulites 


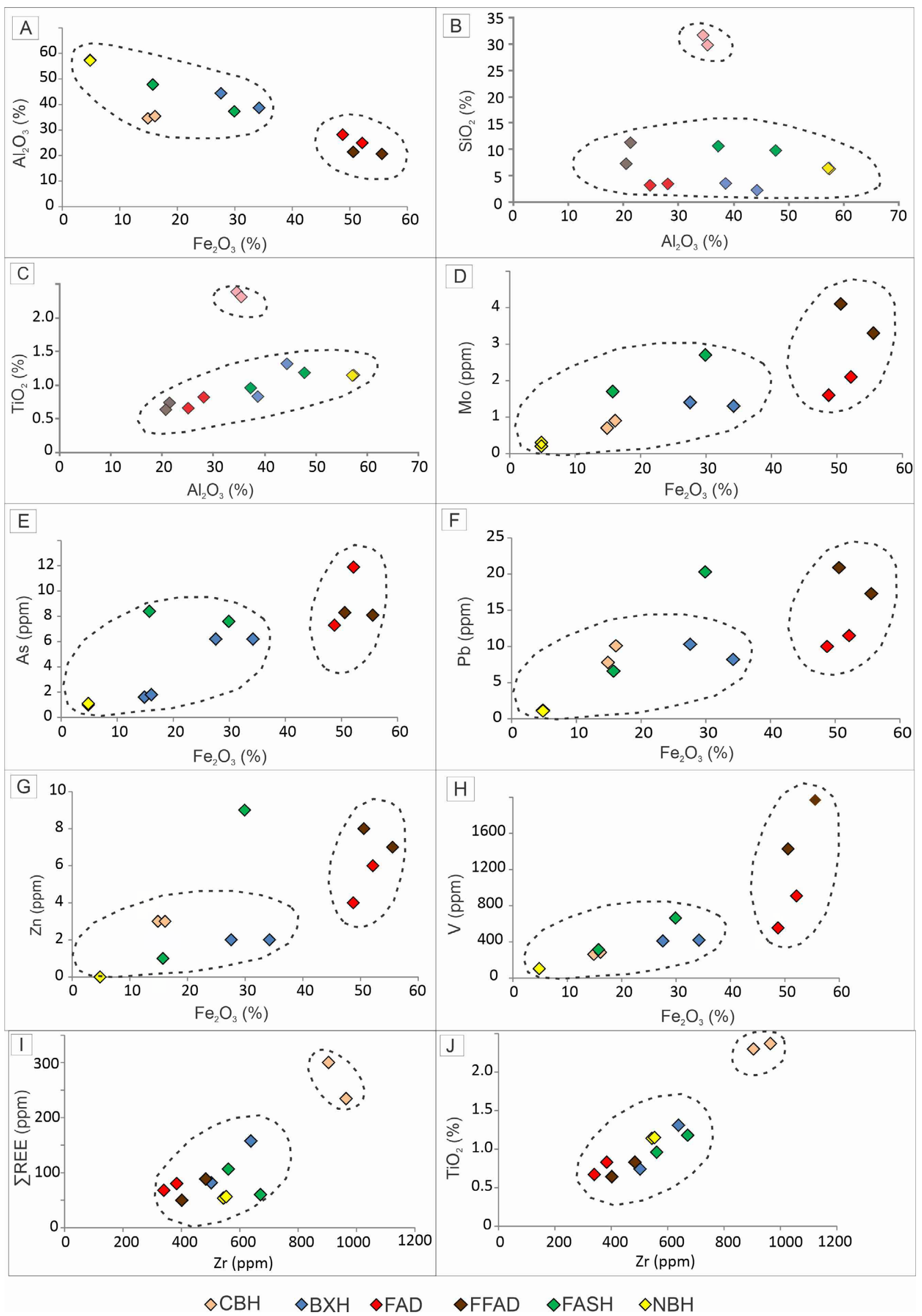

Figure 15. (A) Negative linear correlation between $\mathrm{Fe}_{2} \mathrm{O}_{3} \times \mathrm{Al}_{2} \mathrm{O}_{3} ;$ (B) non-linear distribution $\mathrm{Al}_{2} \mathrm{O}_{3} \times \mathrm{SiO}_{2}$; (C) positive linear correlation $\mathrm{Al}_{2} \mathrm{O}_{3} \times \mathrm{TiO}_{2}$. Trace elements that show positive linear correlation with iron: (D) $\mathrm{Fe}_{2} \mathrm{O}_{3} \times \mathrm{Mo}$; (E) $\mathrm{Fe}_{2} \mathrm{O}_{3} \times \mathrm{As} ;(\mathrm{F}) \mathrm{Fe}_{2} \mathrm{O}_{3} \mathrm{xp}$; (G) $\mathrm{Fe}_{2} \mathrm{O}_{3} \mathrm{x}$ $\mathrm{Zn}$; (I) $\mathrm{Fe}_{2} \mathrm{O}_{3} \times \mathrm{V}$. Zr x $\sum \mathrm{REE}$; (J) $\mathrm{Zr} \times \mathrm{TiO}_{2}$. 
and nodular bauxite) are products of post-lateritic reworking. The distribution of the main chemical components also points to this compartmentalization since the vertical distribution of $\mathrm{Fe}_{2} \mathrm{O}_{3}$, $\mathrm{SiO}_{2}$ and $\mathrm{Al}_{2} \mathrm{O}_{2}$ is contrasting between the two zones.

The fluctuation of $\mathrm{TiO}_{2}$ and $\mathrm{Zr}$ values from the base to the top suggests a heterogeneous protolith, which represents the faciological variation of the Itapecuru Formation. Rare Earth Elements, $\mathrm{Hf}, \mathrm{Nb}$, $\mathrm{Ta}$ and $\mathrm{Y}$ are carried by relic zircon, whereas $\mathrm{Ga}, \mathrm{Cr}, \mathrm{Mo}, \mathrm{As}, \mathrm{Pb}, \mathrm{Hg}, \mathrm{Sb}, \mathrm{Zn}, \mathrm{V}$ and $\mathrm{Sc}$ are mainly present in the iron oxi-hydroxides. Nodules and spherulites register the different evolutionary stages of the lateritic profile, characterized by successive cycles of iron and aluminum oxy-hydroxide aggregation; reworking; and formation of new spherulites that includethe smaller ones.

The Décio lateritic profile and the Itapecuru Formation both exhibit similar but mature heavy mineral associations, making a direct association difficult. However, the behavior of the major and trace elements relative to the isocon suggests a substantial affinity of the $\mathrm{BXH}$ with the $\mathrm{CBH}$ and the Itapecuru claystone. Therefore, the affinity of the BXH with the Itapecuru claystone is confirmed by the mass balance, suggesting that the $\mathrm{CBH}$ corresponds to an intermediary stage of the lateritic evolution.
The base of the Décio lateritic profile $(\mathrm{CBH}, \mathrm{BXH}$ and FAD) was formed under warm and humid conditions. The increase in humidity allowed for the development of a rainforest environment, which degraded the upper part of the profile (FAD) to form the FFAD. The surficial reworking of the lateritic succession, mainly characterized by lateral movement of lateritic materials formed the FASH and the NBH, likely under drier conditions. Therefore, the Décio lateritic succession is an important record of the paleoenvironmental cyclicity of the Eastern Amazon.

\section{ACKNOWLEDGEMENTS}

This research was sponsored by The Brazilian National Council for Scientific and Technological Development (projects 477.411 / 2012-6 and 304.519 / 2009-0); and the National Institute of Science and Technology of Geosciences of the Amazon. For the fieldwork, the authors counted on the assistance of Votorantim Metais S.A. (now Nexa Resources S.A.). The analytical procedures were performed at the Geosciences Institute of the Universidade Federal do Pará facility. The English review was carried out with the assistance of Ms. Lynette Bhabha.

\section{ARTICLE INFORMATION}

Manuscript ID: 20210037. Received on: 05/13/2021. Approved on: 10/30/2021

P.S. was responsible for all the mineralogical, micromorphological and chemical analysis, wrote the original draft of the manuscript and prepared the figures. M.C. conceptualized the research, acquired financial resources, was the advisor and improved the manuscript through corrections and suggestions.

Competing interests: the authors declare no competing interests.

\section{REFERENCES}

Bárdossy G. 1982. Karst bauxites. Amsterdam, Elsevier, 441 p.

Bárdossy G., Aleva G.J.J. 1990. Lateritic bauxites: developments in economic geology. Amsterdam, Elsevier Scientific Publication, 624 p.

Barros A.E., Nardi L.V.S., Dillenburg S.R. 2005. Geoquímica de minerais detríticos em estudos de proveniência: uma revisão. Pesquisas em Geociências, 32(1):3-15

Bizzi L.A., Schobbenhaus C., Vidotti R.M., Gonçalves J.H. (eds.). 2003. Geologia, tectônica e recursos minerais do Brasil. Brasília, Companhia de Pesquisa de Recursos Minerais, $692 \mathrm{p}$.

Boulangé B., Carvalho A. 1997. The bauxite of Porto Trombetas. In Carvalho A., Boulangé B., Melfi A.J., Lucas Y. (eds.). Brazilian Bauxites. São Paulo, USP/FAPESP/ORSTOM, p. 55-73.

Brimhall G.H., Lewis C.J., Ague J.J., Dietrich W.E., Hampel J., Teague T., Rix P. 1988. Metal enrichment in bauxites by deposition of chemically mature aeolian dust. Nature, 333:819-824. https://doi.org/10.1038/333819a0

Calagari A.S., Abedini A. 2007. Geochemical investigations on PermoTriassic bauxite horizon at Kanisheeteh, east of Bukan, West-Azarbaidjan, Iran. Journal of Geochemical Exploration, 94(1-3):1-18. https://doi. org/10.1016/j.gexplo.2007.04.003

Colin F., Brimhall G.H., Nahon D., Baronnet A., Kathy D. 1992. Equatoria rainforest lateritic mantles: a geomembrane filter. Geology, 20(6):523-526. https://doi.org/10.1130/0091-7613(1992)020\%3C0523:ERFLMA\%3E 2.3.CO;2

Costa M.L. 1991. Aspectos geológicos dos lateritos da Amazônia. Revista Brasileira de Geociências, 21(2):146-160.
Costa M.L. 2016. Alumínio e bauxita no Brasil. In: Melfi A.J., Misi A., Campos D.A., Cordani U.G. (eds.). Recursos minerais no Brasil: problemas e desafios. Rio de Janeiro, Academia Brasileira de Ciências, p. 166-173.

Costa M.L., Cruz G.S., Almeida H.D.F., Poellmann H. 2014. On the geology, mineralogy and geochemistry of the bauxite-bearing regolith in the lower Amazon Basin: evidence of genetic relationships. Journal of Geochemical Exploration, 146:58-74. https://doi.org/10.1016/j. gexplo.2014.07.021

Cruz G.S. 2011. Bauxita, horizonte nodular e cobertura argilosa da região de Paragominas e Juruti, estado do Pará. MS Dissertation, Universidade Federal do Pará, Belém, 93 p.

Dantas M.E., Teixeira S.G. 2013. Origem das paisagens. In: João X.S.J., Teixeira S.G., Fonseca D.D.F. (eds.). Geodiversidade do Estado do Pará. Brasília, Companhia de Pesquisa de Recursos Minerais.

Delvigne J.E. 1999. Atlas of micromorphology of mineral alteration and weathering. Ottawa, The Canadian Mineralogist Special Publication, 495 p.

Diko L., Vervoort A., Vergauwen I. 2001. Geostatistical modelling of lateritic bauxite orebodies in Suriname: effect of the vertical dimension. Journal of Geochemical Exploration, 73(3):131-153.

Evensen N.M., Hamilton P.J., O’Nions R.K. 1978. Rare-earth abundance in chondritic meteorites. Geochimica et Cosmochimica Acta, 42(8):11991212. https://doi.org/10.1016/0016-7037(78)90114-X

Góes A.M. 1995. A Formação Poti (Carbonífero Inferior) da Bacia do Parnaíba. PhD Thesis, Universidade de São Paulo, São Paulo, 171 p.

Grant J.A. 1986. The Isocon diagram-a simple solution to Gresens equation for metasomatic alteration. Economic Geology, 81 (8):1976-1982. https://doi.org/10.2113/gsecongeo.81.8.1976 
Grubb P.L.C. 1979. Genesis of Bauxite deposits in the Amazon basin and Guianas coastal plain. Economic Geology, 74(4):735-750. https://doi. org/10.2113/gsecongeo.74.4.735

Gu J., Huang Z., Fan H., Jin Z., Yan Z., Zhang J. 2013. Mineralogy, geochemistry, and genesis of lateritic bauxite deposits in the WuchuanZheng'an area, Northern Guizhou Province, China. Journal of Geochemical Exploration, 130:44-59. https://doi.org/10.1016/j.gexplo.2013.03.003

Hanilçi N. 2013. Geological and geochemical evolution of the Bolkardaği bauxite deposits, Karaman, Turkey: Transformation from shale to bauxite. Journal of Geochemical Exploration, 133:118-137. https://doi. org/10.1016/j.gexplo.2013.04.004

Henderson P. 1984. Rare Earth element geochemistry. Amsterdam, Elsevier Science, $520 \mathrm{p}$

Hieronymus B., Kotschoubey B., Boulègue J. 2001. Gallium behaviour in some contrasting lateritic profiles from Cameroon and Brazil. Journal of Geochemical Exploration, 72(2):147-163. https://doi.org/10.1016/ S0375-6742(01)00160-1

Hill I.G., Worden R.H., Meighhan I.G. 2000. Geochemical evolution of a palaeolaterite: the Interbasaltic Formation, Northern Ireland. Chemical Geology, 166(1-2):65-84. https://doi.org/10.1016/ S0009-2541(99)00179-5

Horbe A.M.C., Anand R.R. 2011. Bauxite on igneous rocks from Amazonia and Southwestern of Australia: implication for weathering process. Journal of Geochemical Exploration, 111(1-2):1-12. https://doi.org/10.1016/j. gexplo.2011.06.003

Horbe A.M.C., Costa M.L. 1999. Relações genéticas entre latossolos e crostas lateríticas aluminosas e alumino-ferruginosas na região de Paragominas, Pará. Revista Brasileira de Geosciências, 29(4):497-504.

Horbe A.M.C., Costa M.L. 2005 Lateritic crusts and related soils in eastern Brazilian Amazonia. Geoderma, 126(3-4):225-239. https://doi. org/10.1016/j.geoderma.2004.09.011

Hou Y., Zhong Y., Zu Y., He B. 2017. The provenance of late Permian karstic bauxite deposits in SW China, constrained by the geochemistry of interbedded clastic rocks, and $\mathrm{U}-\mathrm{Pb}-\mathrm{Hf}-\mathrm{O}$ isotopes of detrital zircons. Lithos, 278-281:240-254. https://doi.org/10.1016/j.lithos.2017.01.013

Kelepertsis A.E. 2002. Mineralogy and geochemistry of the pliocene ironrich laterite in the Vatera Area, Lesvos Island, Greece and its Genesis. Chinese Journal of Chemistry, 21(3):193-205. https://doi.org/10.1007/ BF02831084

Kotschoubey B., Truckenbrodt W., Calaf J.M.C. 2005. Evolução geológica da porção meridional da Província Bauxitífera de Paragominas durante o Neógeno/Pleistoceno (Noroeste da Bacia do Grajaú, Nordeste do Pará e extremo Oeste do Maranhão). Revista Brasileira de Geociências, 35(2):263-272.

Kotschoubey B., Truckenbrodt W., Hieronymus B. 1987. Phases and zonality of the bauxitic alteration in the northeast of the State of Pará (Brazil). Travaux ICSOBA, 16-17:115-127.

Lima J.D.O. 2018. Micromorfologia, mineralogia e geoquímica da bauxita nodular de Trombetas - PA. MS Dissertation, Universidade Federal do Pará, Belém.

Ling K.Y., Tang H.S., Zhang Z.W., Wen H.J. 2020. Host minerals of Li$\mathrm{Ga}-\mathrm{V}$-rare earth elements in Carboniferous karstic bauxites in southwest China. Ore Geology Reviews, 119:103-325. http://doi.org/10.1016/j. oregeorev.2020.103325

Linnen R.L., Samson L., Breaks F.W. (eds.). 2005. Rare-element geochemistry and mineral deposits. Ontario, Geological Association of Canada.

Liu X.F., Wang Q.F., Feng Y.W., Li Z.M., Cai S.H. 2013. Genesis of the Guangou karstic bauxite deposit in western Henan, China. Ore Geology Reviews, 55:162-175. https://doi.org/10.1016/j. oregeorev.2013.06.002

Lucas Y. 1997. The bauxite of Juruti. In: Carvalho A., Boulangé B., Melfi A.J., Lucas Y. (eds.). Brazilian Bauxites. São Paulo, USP/FAPESP/ORSTOM, p. 107-133.

McAlister J.J., Smith B.J. 1997. Geochemical trends in early Tertiary palaeosols from Northeast Ireland: a statistical approach to assess element behavior during weathering. Geological Society of London Especial Publication, 120:57-65. https://doi.org/10.1144/GSL.SP.1997.120.01.05

Meyer F.M., Happel U., Hausberg J., Wiechowski A. 2002. The geometry and anatomy of the Los Pijiguaos bauxite deposit, Venezuela. Ore Geology Reviews, 20(1-2):27-54. https://doi.org/10.1016/ S0169-1368(02)00037-9

Momo M.N., Beauvais A., Tematio P., Yemefack M. 2020. Differential Neogene bauxitization of volcanic rocks (western Camaroon): Morphogeological constrains on chemical erosion. Catena, 194:104685. https:// doi.org/10.1016/j.catena.2020.104685

Mongelli G., Boni M., Buccione R., Sinisi R. 2014. Geochemistry of the Apulian karst bauxites (southern Italy): chemical fractionation and parental affinities. Ore Geology Reviews, 63:9-21. https://doi.org/10.1016/j. oregeorev.2014.04.012

Monsels D.A., Van Bergen M.J. 2017. Bauxite formation on Proterozoic bedrock of Suriname. Journal of Geochemical Exploration, 180:71-90. https://doi.org/10.1016/j.gexplo.2017.06.011

Mordberg L.E. 1993. Patterns of distribution and behavior of trace elements in bauxites. Chemical Geology, 107(3-4):241-244. https://doi. org/10.1016/0009-2541(93)90183-J

Nascimento M.S., Góes A.M. 2007. Petrografia de arenitos e minerais pesados de depósitos cretáceos (Grupo Itapecuru), Bacia de São LuísGrajaú, norte do Brasil. Revista Brasileira de Geociências, 37(1):1-15.

Negrão L.B.A., Costa M.L. 2021. Mineralogy and geochemistry of a bauxite-bearing lateritic profile supporting the identification of its parent rocks in the domain of the huge Carajás iron deposits, Brazil. Journal of South American Earth Sciences, 108:103164. https://doi.org/10.1016/j. jsames.2021.103164

Negrão L.B.A., Costa M.L., Pöllmann H. 2018. The Belterra Clay on the bauxite deposits of Rondon do Pará, Eastern Amazon. Brazilian Journal of Geology, 48(3):473-484. https://doi. org/10.1590/2317-4889201820180128

Nesbitt H.W. 1979. Mobility and fractionation of rare earth elements during weathering of a granodiorite. Nature, 279:206-210. https://doi. org $/ 10.1038 / 279206 \mathrm{a} 0$

Oliveira S.B., Costa M.L., Prazeres Filho H. 2016. The lateritic bauxite deposit of Rondon do Pará: a new giant deposit in the Amazon Region, northern Brazil. Economic Geology, 111(5):1277-1290. https://doi. org/10.2113/econgeo.111.5.1277

Pantoja H.M. 2015. Mineralogia, geoquímica e minerais pesados do perfil laterito-bauxítico com cobertura e sua relação com o Grupo Itapecuru: lavra piloto Ciríaco (Rondon do Pará). MS Dissertation, Universidade Federal do Pará, Belém, 73 p.

Radusinović S., Jelenković R., Pačevski A., Simić V., Božović D., HolclajtnerAntunović I., Životić D. 2017. Content and mode of occurrences of rare earth elements in the Zagrad karstic bauxite deposit (Nikšić area, Montenegro). Ore Geology Reviews, 80:406-428. https://doi. org/10.1016/j.oregeorev.2016.05.026

Rossetti D.F. 2001. Arquitetura deposicional da Bacia de São LuísGrajaú. In: Rossetti D.F., Góes A.M., Truckenbrodt W. (eds.). O Cretáceo na Bacia de São Luís-Grajaú. Belém, Museu Paraense Emílio Goeldi, p. 31-46.

Rudnick R.L., Gao S. 2003. Composition of the continental crust. In: Rudnick R.L. (ed.). The Crust, 3. Amsterdam, Elsevier, p. 1-64.

Salamab-Ellahi S., Taghpour B., Mongelli G. 2019. Clayey bauxite from the Irano-Himalayan belt: Critical metals, provenance and palaeoclimate in the Upper Cretaceous Semirom ore deposit, Zagros Mountain, Iran. Journal of Asian Earth Sciences, 172:126-142. https://doi.org/10.1016/j. jseaes.2018.09.001

Santos S.H.G., Jacomine P.K.T., Anjos L.H.C., Oliveira V.A., Lumbreras J.F., Coelho M.R., Almeida J.A., Araujo Filho J.C., Oliveira J.B., Cunha T.J.F. 2018. Brazilian soil classification system. 5. ed. Brasília, EMBRAPA, 356 p.

Schellmann W. 1983. A new definition of laterite. Geological Survey of India Memoirs, 120:1-7.

Tardy Y. 1997. Petrology of laterites and tropical soil. Rotterdam, Balkema, $408 \mathrm{p}$. 
Théveniaut H., Freyssinet P. 2002. Timing of lateritization on the Guiana Shield: synthesis of palaeomagnetic results from French Guiana and Suriname. Paleogeography, Palaeoclimatology, Palaeoecology, 178(12):91-117. https://doi.org/10.1016/S0031-0182(01)00404-7

Truckenbrodt W., Kotschoubey B. 1981. Argila de Belterra - cobertura terciária das bauxitas amazônicas. Revista Brasileira de Geociências, 11(3):203-208.

Truckenbrodt W., Kotschoubey B., Hieronymus B. 1995. Aluminization: an important process in the evolution of Amazonian bauxites. Travaux ICSOBA, 22(1):27-42.

Valeton I. 1972. Bauxites: development in soils sciences. Amsterdam, Elsevier, $226 \mathrm{p}$.

Vasconcelos P.M., Reich M., Shuster D.L. 2015. The paleoclimatic signatures of supergene metal deposits. Elements, 11(5):317-322. https:// doi.org/10.2113/gselements.11.5.317
Vaz P.T., Rezende Filho N.G.A.M., Travassos W.A.S. 2007. Bacia do Parnaíba. Boletim de Geociências da Petrobras, 15(2):253-263.

Wang Q.F., Liu X.F., Yan C.H., Cai S.H., Li Z.M., Wang Y.R., Zhao J.M., Li G.J. 2012. Mineralogical and geochemical studies of boronrich bauxite ore deposits in the Songqi region, SW Henan, China. Ore Geology Reviews, 48:258-270. https://doi.org/10.1016/j. oregeorev.2012.04.004

Yuste A., Bauluz B., Mayayo M.J. 2017. Origin and geochemical evolution from ferrallitized clays to karst bauxite: an example from the Lower Cretaceous of NE Spain. Ore Geology Reviews, 84:67-79. https://doi. org/10.1016/j.oregeorev.2016.12.025

Zamanian H., Ahmadnejad F., Zarasvandi A. 2015. Mineralogical and geochemical investigations of the Mombi bauxite deposit, Zagros Mountains, Iran. Chemie der Erde Geochemistry, 76(1):13-37. https:// doi.org/10.1016/j.chemer.2015.10.001 